\title{
NBS TECHNICAL NOTE 932
}

\section{U.S. DEPARTMENT OF COMMERCE / National Bureau of Standards}

\section{Concrete Strength During Construction}

QC

100

.45753

No.932

1976

c. 2 
The National Bureau of Standards ${ }^{1}$ was established by an act of Congress March 3, 1901. The Bureau's overall goal is to strengthen and advance the Nation's science and technology and facilitate their effective application for public benefit. To this end, the Bureau conducts research and provides: (1) a basis for the Nation's physical measurement system, (2) scientific and technological services for industry and government, (3) a technical basis for equity in trade, and (4) technical services to promote public safety. The Bureau consists of the Institute for Basic Standards, the Institute for Materials Research, the Institute for Applied Technology, the Institute for Computer Sciences and Technology, and the Office for Information Programs.

THE INSTITUTE FOR BASIC STANDARDS provides the central basis within the United States of a complete and consistent system of physical measurement; coordinates that system with measurement systems of other nations; and furnishes essential services leading to accurate and uniform physical measurements throughout the Nation's scientific community, industry, and commerce. The Institute consists of the Office of Measurement Services, the Office of Radiation Measurement and the following Center and divisions:

Applied Mathematics - Electricity - Mechanics - Heat - Optical Physics - Center for Radiation Research: Nuclear Sciences; Applied Radiation — Laboratory Astrophysics ${ }^{2}$ - Cryogenics $^{2}$ - Electromagnetics ${ }^{2}$ — Time and Frequency ${ }^{2}$.

THE INSTITUTE FOR MATERIALS RESEARCH conducts materials research leading to improved methods of measurement, standards, and data on the properties of well-characterized materials needed by industry, commerce, educational institutions, and Government; provides advisory and research services to other Government agencies; and develops, produces, and distributes standard reference materials. The Institute consists of the Office of Standard Reference Materials, the Office of Air and Water Measurement, and the following divisions:

Analytical Chemistry - Polymers - Metallurgy - Inorganic Materials — Reactor Radiation - Physical Chemistry.

THE INSTITUTE FOR APPLIED TECHNOLOGY provides technical services to promote the use of available technology and to facilitate technological innovation in industry and Government; cooperates with public and private organizations leading to the development of technological standards (including mandatory safety standards), codes and methods of test; and provides technical advice and services to Government agencies upon request. The Institute consists of the following divisions and Centers:

Standards Application and Analysis - Electronic Technology - Center for Consumer Product Technology: Product Systems Analysis; Product Engineering - Center for Building Technology: Structures, Materials, and Life Safety; Building Environment; Technical Evaluation and Application - Center for Fire Research: Fire Science; Fire Safety Engineering.

THE INSTITUTE FOR COMPUTER SCIENCES AND TECHNOLOGY conducts research and provides technical services designed to aid Government agencies in improving cost effectiveness in the conduct of their programs through the selection, acquisition, and effective utilization of automatic data processing equipment; and serves as the principal focus within the executive branch for the development of Federal standards for automatic data processing equipment, techniques, and computer languages. The Institute consists of the following divisions:

Computer Services — Systems and Software - Computer Systems Engineering - Information Technology.

THE OFFICE FOR INFORMATION PROGRAMS promotes optimum dissemination and accessibility of scientific information generated within NBS and other agencies of the Federal Government; promotes the development of the National Standard Reference Data System and a system of information analysis centers dealing with the broader aspects of the National Measurement System; provides appropriate services to ensure that the NBS staff has optimum accessibility to the scientific information of the world. The Office consists of the following organizational units:

Office of Standard Reference Data - Office of Information Activities - Office of Technical Publications - Library - Office of International Relations - Office of International Standards.

\footnotetext{
Headquarters and Laboratories at Gaithersburg. Maryland, unless otherwise noted; mailing address Washington, D.C. 20234.

"Located at Boulder, Colorado 80302 .
} 
H. S. Lew, T. W. Reichard, and

J. R. Clifton

Center for Building Technology

Institute for Applied Technology

National Bureau of Standards

Washington, D.C. 20234

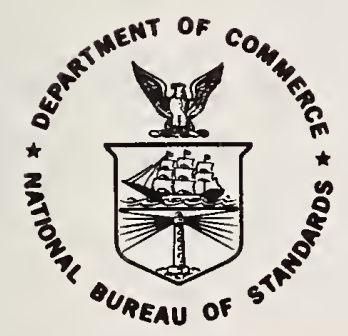

U.S. DEPARTMENT OF COMMERCE, Elliot L. Richardson, Secretary

Edward O. Vetter, Under Secretary

Dr. Betsy Ancker-Johnson, Assistant Secretary for Science and Technology

NATIONAL BUREAU OF STANDARDS, Ernest Ambler, Acting Director 


\section{National Bureau of Standards Technical Note 932}

Nat. Bur. Stand. (U.S.), Tech. Note 932, 56 pages (Dec. 1976)

CODEN: NBTNAE 


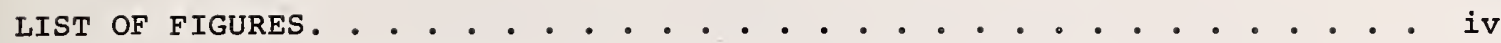

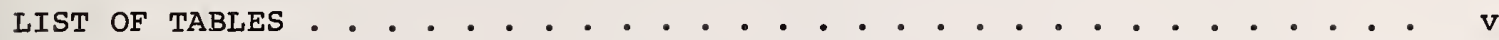

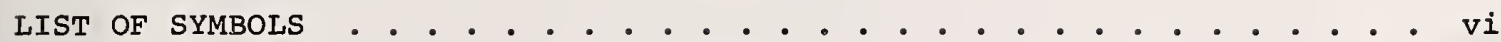

Abstract . . . . . . . . . . . . . . . . . . . . . . . . . . 1

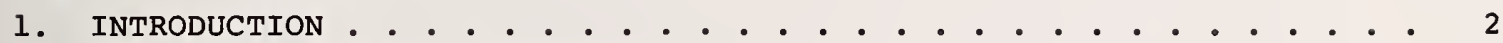

1.1 Background and Purpose. . . . . . . . . . . . . . . . . . . . 2

1.2 Scope . . . . . . . . . . . . . . . . . . . . . . . 3

2. DESCRIPTION OF TESTS . . . . . . . . . . . . . . . . . . . . . . . 4

2.1 Preparation of Test Specimens . . . . . . . . . . . . . . . . . 4

2.1 .1 Description of Test Specimens. . . . . . . . . . . . . . 4

2.1 .2 Concrete . . . . . . . . . . . . . . . . . . . . . 4

2.2 Curing Procedure. . . . . . . . . . . . . . . . . . . . . . 5

2.3 Test Procedure. . . . . . . . . . . . . . . . . . 5

2.3 .1 General. . . . . . . . . . . . . . . . . . . . . 5

2.3.2 Compressive Strength Test. . . . . . . . . . . . . . . . 5

2.3.3 Splitting Tensile Strength Test. . . . . . . . . . . . . 6

2.3.4 Pull-Out Bond Strength Test. . . . . . . . . . . . . . . 6

2.3.5 Probe Penetration Test . . . . . . . . . . . . . . . 7

2.3 .6 Rebound Hammer Test. . . . . . . . . . . . . . . . . . . 7

3. TEST RESULTS AND DISCUSSION. • • . . . . . . . . . . . . . . . . . . 8

3.1 General . . . . . . . . . . . . . . . . . . . . . . . 8

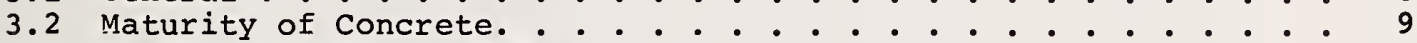

3.3 Compressive Strength Test . . . . . . . . . . . . . . . . . . . 9

3.4 Modulus of Elasticity . . . . . . . . . . . . . . . . . . . . . 11

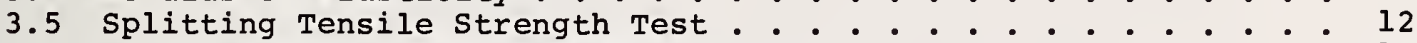

3.6 Pull-out Bond Strength Test . . . . . . . . . . . . . . . . . . . . . 12

3.7 Rate of Strength and Modulus Gain with Maturity . . . . . . . . 13

3.8 Non-Destructive Tests . . . . . . . . . . . . . . . . . . 14

3.8.1 Probe Penetration. . . . . . . . . . . . . . . . . 14

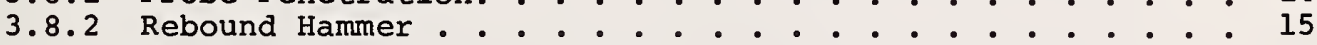

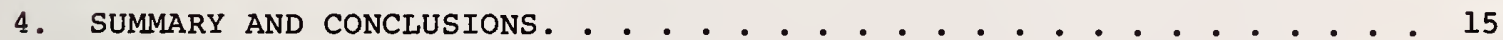

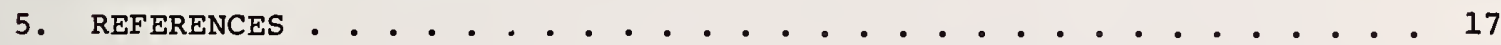


Page

Figure 1. Section Through Pull-out Specimen Rack and Mold . . . . . 29

Figure 2. Compressive Test of Cylinder. . . . . . . . . . . . . 30

Figure 3. Splitting Tensile Test of Cylinder. . . . . . . . . . . 31

Figure 4. Pull-out Test Setup . . . . . . . . . . . . . . . 32

Figure 5. Pull-out Bond Test. . . . . . . . . . . . . . . 33

Figure 6. Probe Penetration Test. . . . . . . . . . . . . . . . 34

Figure 7. A Device Used to Measure the Average Penetration of Three Probes. . . . . . . . . . . . . . . . 35

Figure 8. Rebound Hammer Test . . . . . . . . . . . . . . 36

Figure 9. Cylinder Temperatures During Curing Period. . . . . . . . . 37

Figure 10. Compressive Strength Versus lfaturity. . . . . . . . . . 38

Figure 11. The Lower and Upper Limits of Intercepts and Slopes of Regression Lines of Compressive Strength Versus Maturity. . 39

Figure 12. Typical Stress-Strain Curves of Compressive Tests of

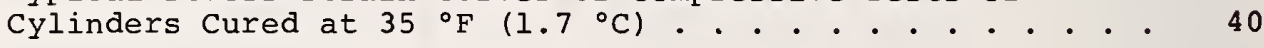

Figure 13. Secant Modulus Versus Maturity. . . . . . . . . . . . . . 4 41

Figure 14. The Lower and Upper Limits of Intercepts and Slopes of Regression Lines of Secant Modulus Versus Maturity. . . . . 42

Figure 15. Splitting Tensile Strength Versus Maturity. . . . . . . . . 43

Figure 16. The Lower and poper Limits of Intercepts and Slopes of Regression Lires of Splitting Tensile Strength Versus Maturity. ...................... 44

Figure 17. Pull-out Load Versus Maturity . . . . . . . . . . . . . 45

Figure 18. The Lower and Upper Limits of Intercepts and Slopes of Regression Lines of Pull-out Load Versus Maturity . . . . . 46

Figure 19. Normalized Mechanical Properties With Respect to 28-Day, Values Versus Maturity .. . . . . . . . . . . . 47

Figure 20. Comparison of Measured Compressive Strength Versus Compressive Strength from Probe Chart . . . . . . . . . 


\section{LIST OF TABLES}

Page

Table 1. Distribution of Test Specimens to Three Curing Conditions. . 20

Table 2. Compressive Strength Test Results. . . . . . . . . . . . . . . 21

Table 3. Splitting Tensile Strength Test Results. . . . . . . . . . . . 22

Table 4. Pull-Out Bond Strength Test Results . . . . . . . . . . . 23

Table 5. Probe Penetration Test Results . . . . . . . . . . . . . . . . 24

Table 6. Rebound Hammer Test Results. . . . . . . . . . . . . . . 25

Table 7. Mean Temperature of Concrete During Each Age Interval. . • . 26

Table 8. Maturity Value of Concrete . . . . . . . . . . . . . 27

Table 9. Statistical Properties Associated with the Regression

Equations. . . . . . . . . . . . . . . . . 28 


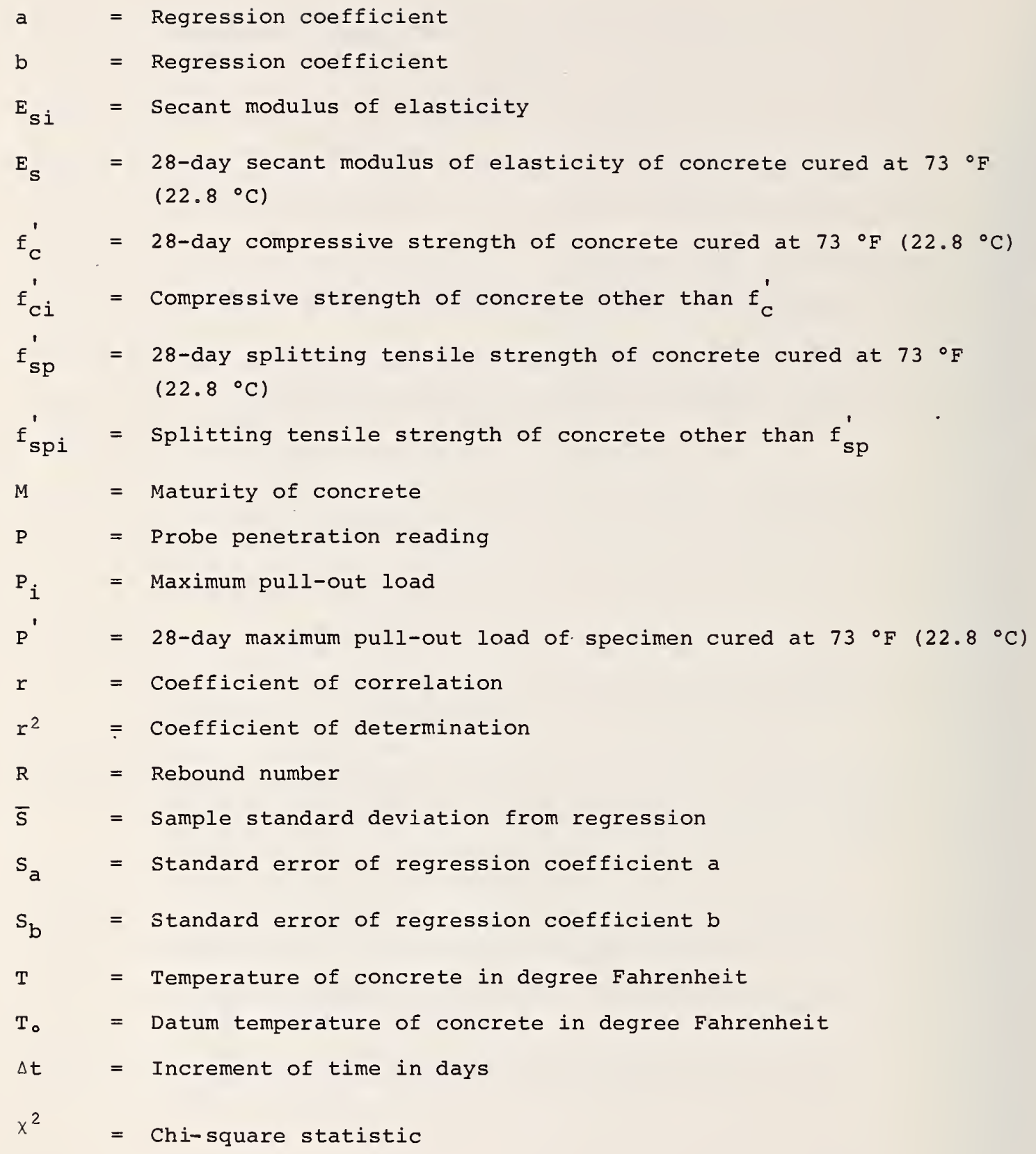


The early strength gain characteristics of a concrete at various temperatures was investigated in this study. In addition, the applicability of two widely known non-destructive evaluation methods were examined for the purpose of determining the compressive strength of concrete at early ages.

For destructive evaluation, standard cylinder compression tests, splitting tensile tests and pull-out tests were made on specimens cured at $73^{\circ} \mathrm{F}\left(22.8^{\circ} \mathrm{C}\right), 55^{\circ} \mathrm{F}\left(12.8^{\circ} \mathrm{C}\right)$ and $35^{\circ} \mathrm{F}$ $\left(1.7^{\circ} \mathrm{C}\right)$. For non-destructive evaluation, both probe penetration and rebound hammer tests were performed on slabs. Tests were carried out at the age of $1,2,3,5,7,14,28$ and 42 days after casting the concrete.

Statistical analyses were made to examine the possibility of using maturity of concrete as a parameter to correlate test results of concrete cured at different temperatures. Rate of gain of the splitting tensile strength, pull-out bond strength and elastic modulus were compared with that of compressive strength.

The results show that when related to maturity, the rate of increase in the splitting tensile strength is about the same as that of the compressive strength, whereas the rate of increase in the pull-out strength and the modulus are slightly greater than that of the compressive strength. The results of non-destructive evaluations revealed that the compressive strength could not be estimated correctly by the probe method using the manufacturer's conversion charts. Because of lower rebound readings, the rebound hammer could not be used to estimate the compressive strength at early ages.

Key words: Compressive strength; concrete; maturity; mechanical properties; non-destructive evaluation; pull-out strength; splitting tensile strength. 


\section{INTRODUCTION}

\subsection{Background and Purpose}

In recent years there have been a number of failures of large concrete structures $[1,2]^{1}$ during construction. Although the specific factors which triggered the failures may have been different, the main reason for the failures was the inadequacy, or absence of shoring necessary to support the partially matured concrete structure. The decision as to when shores and/or forms can be removed safely and how many levels of previously cast floors need to be reshored to support construction loads is based primarily on the rate of strength gain in the concrete and/or on the determination of in-situ strength of concrete.

Considerable information exists on the development of the compressive strength of concrete $[3,4]$ under varying temperature and moisture conditions. These investigations have shown that the compressive strength can generally be predicted if the curing history, in terms of temperature, moisture and age, is known. However, the strength of flexural members such as beams and slabs are often governed by either shear (diagonal tension) or bond strength at early ages. It is usually assumed that these strength parameters are related to some function of the compressive strength $[5,6]$. The most common assumption is that they vary with the square root of the compressive strength. To date, no systematic investigation has been made to substantiate this functional relationship at early ages. Accordingly, one objective of this investigation was to determine the interrelationships between the compressive-strength gain of concrete with its strength gain in shear and bond and with the increase in modulus of elasticity.

In-situ strength of concrete members is usually determined from results of compressive tests of job-cured cylinders. Investigations $[7,8]$ have shown that the results from cylinder tests, even when cured at the job site, generally do not correlate consistantly with the strength of structural members. This inconsistency stems primarily from the difference in curing conditions because of shape and massiveness of section.

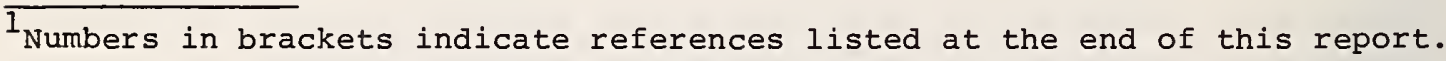


In order to overcome the difficulty of simulating curing conditions, test results of cores taken from structural members are sometimes used to determine the concrete strength of those members. The variability in test results for cores is significantly greater than for the cylinder test, however. In a series of cylinder and core tests [7], the coefficient of variation for 216 core tests was 3.9 percent and for 216 cylinder tests was 2.4 percent. This shows that dispersion of core test results is greater than that of cylinder test results. The dispersion becomes greater as the number of tests becomes smaller. Because it is difficult and time consuming to mold, cure and test large numbers of cylinders or to remove cores, it would be desirable to have a reasonably accurate non-destructive test method for determination of the strength of concrete. Thus, the other objective of this investigation was to evaluate existing non-destructive evaluation (NDE) methods in determining the compressive strength of concrete at early ages. Two NDE methods, probe penetration (Windsor Probe) ${ }^{2}$ and rebound hammer (Schmidt Hammer), ${ }^{2}$ were evaluated in this study, and they are described in reference 9.

\subsection{Scope}

Since the purpose of this test series was to determine only the relative relationships between the several strength and stiffness properties of a specific concrete at early ages, the tests were designed to be as simple as possible. Three types of destructive tests and two types of non-destructive tests were performed. They are:

\section{Destructive Tests}

1. Compressive strength test of cylindrical specimens

2. Splitting tensile strength test of cylindrical specimens

3. Bond strength test using cylindrical pull out specimens

\section{Non-destructive Tests}

1. Probe-penetration test on slab specimens

2. Rebound-hammer test on slab specimens

${ }^{2}$ Proprietory names. These brand names are used merely to accurately identify the equipment used and their use does not imply an endorsement by the National Bureau of Standards. 
All five types of tests were made on specimens cured at three different temperatures, $35^{\circ} \mathrm{F}\left(1.7{ }^{\circ} \mathrm{C}\right), 55^{\circ} \mathrm{F}\left(12.8^{\circ} \mathrm{C}\right)$, and $73^{\circ} \mathrm{F}\left(22.8^{\circ} \mathrm{C}\right)$; and tested at nine ages, $1,2,3,5,7,14,21,28$ and 42 days.

\section{DESCRIPTION OF TESTS}

\subsection{Preparation of Test Specimens}

\subsubsection{Description of Test Specimens}

Three types of concrete specimens were used. For the compressive and splitting tests, conventional $6 \times 12$ in $(15 \times 30 \mathrm{~cm})$ cylinders were cast in waxed cardboard molds. For the NDE tests, unreinforced $3 \mathrm{ft} \times 5 \mathrm{ft} \times 5-1 / 2$ in thick $(0.915 \mathrm{~m} \times 1.525 \mathrm{~m} \times 140 \mathrm{~mm})$ slabs were cast in oiled wood forms.

The pull-out specimens for the relative bond-strength tests consisted of a 48 in $(1.2 \mathrm{~m})$ long No. $6(3 / 4$ in or $19 \mathrm{~mm})$ deformed reinforcing bar $(62.3$ $\mathrm{ksi}$, or $429.6 \mathrm{MPa}$ yield) cast in a $6 \times 8$ in $(15 \times 20 \mathrm{~cm})$ waxed cardboard cylinder mold. Figure 1 shows the pull-out specimen and mold. The specimens were made so that the bar was bonded to the concrete for a length of 6 inches $(15.2 \mathrm{~cm})$ in all specimens. The pull-out molds were set up for casting in gang racks holding 6 specimens each. The racks were designed to rigidly hold each bar in a vertical position during the casting operation and during curing. The metal bottom of each cylinder mold had a hole drilled in it so that the bottom end of the bar would extend into a hole in the plywood base of the rack. A plastic furniture tip over the end of the bar sealed the hole in the bottom of the mold and protected the end of the bar. The concrete cylinder of each pull-out specimen was reinforced with a 4.5 in $(11.4 \mathrm{~cm}$ ) diameter cage made of 2 in $\times 2$ in $(5 \mathrm{~cm} \mathrm{x} 5 \mathrm{~cm})$ welded steel wire mesh of 16 gage $(0.0625$ in or $1.59 \mathrm{~mm})$.

Table 1 lists the specimens cast and the temperatures at which they were cured.

\subsubsection{Concrete}

The concrete was supplied by a local ready-mix company in a $3 \mathrm{yd}^{3}\left(2.3 \mathrm{~m}^{3}\right)$ batch and was one of their standard mixes. The mix proportions for per cubic yard of concrete were:

$\begin{array}{rll}517 & \text { lbs }(235 \mathrm{~kg}) & \text { Type I Cement } \\ 1365 & \text { lbs }(619 \mathrm{~kg}) & \text { Silica Sand } \\ 1750 & \text { lbs }(794 \mathrm{~kg}) & \text { Crushed Limestone (Maximum size, } 3 / 4 \text { in or } 1.9 \mathrm{~cm}) \\ 6 \mathrm{oz} & (170 \mathrm{~g}) & \text { Air Entraining Agent }\end{array}$


Water was added to provide a $3-1 / 2$ in $(8.9 \mathrm{~cm})$ slump after $15 \mathrm{~min}$ of mixing. This mix resulted in a concrete containing 4-1/2 percentair and weighing $145.8 \mathrm{lb} / \mathrm{ft}^{3}\left(2335 \mathrm{~kg} / \mathrm{m}^{3}\right)$ when placed. (Subsequently, the unit weight of the hardened concrete in the $6 \times 12$ in $(15 \times 30 \mathrm{~cm})$ cylinders was determined to be $146.3 \mathrm{lb} / \mathrm{ft}^{3}\left(2343 \mathrm{~kg} / \mathrm{m}^{3}\right)$. A total of 2 hours was required to $\mathrm{mix}$ and place the concrete. Internal vibration was used to consolidate the concrete in the slabs and $6 \times 12$ in $(15 \times 30 \mathrm{~cm})$ cylinders. Rodding was used for the pull-out specimens. It should be noted that loss in slump was experienced because of the extended period required to place the test specimens.

\subsection{Curing Procedures}

The pull-out specimens and the NDE slabs were cast in the curing chambers which were temperature controlled. The compressive and splitting tensile test specimens were cast at a central location and then distributed to the curing chambers. Because humidities within the chambers were uncontrolled, the specimens were covered with polyethylene film to retard loss of moisture except for six pull-out specimens in each chamber which were sealed by seating steel capping plates on top of the fresh concrete. These "capped" specimens were tested when the concrete was 1 and 2 days old.

The nominal temperatures within the three chambers were $73^{\circ} \mathrm{F}\left(22.8^{\circ} \mathrm{C}\right)$, $55^{\circ} \mathrm{F}\left(12.8^{\circ} \mathrm{C}\right)$ and $35^{\circ} \mathrm{F}\left(1.7^{\circ} \mathrm{C}\right)$. The actual temperatures of the chambers and of the concrete within the chamber were recorded periodically. The temperature of the concrete was measured with a thermocouple cast in a $6 \mathrm{x} 12$ in $(15 \times 30 \mathrm{~cm})$ cylinder stored in each chamber. All specimens were stored in the chambers until each test day.

\subsection{Test Procedures}

\subsubsection{General}

Three specimens from each curing condition were tested for each destructive test on scheduled test dates. The capping and testing of the cylinder specimens were done in a $70^{\circ} \mathrm{F}\left(21{ }^{\circ} \mathrm{C}\right)$ environment.

\subsubsection{Compressive Strength Test}

For tests prior to 7 days each compressive test specimen was capped with a sulphur-silica compound at least one hour before test. For the 7-day and later tests the specimens were capped at least 2 days prior to test. After capping, these specimens were returned to the curing chamber and placed in plastic bags. 
The compressive tests were performed in a hydraulic testing machine essentially as described by ASTM C39-72 [10]. The rate of loading was adjusted to be approximately $1 / 3$ of the expected maximum load per minute. Figure 2 shows the compressive test setup.

Deformation of each specimen was measured during the compressive tests over a gage length of 8 inches $(20.3 \mathrm{~cm})$ with a compressometer such as is described in ASTM C 469-65 [10]. The output from a linear variable differential transformer (LVDT) mounted on the compressometer was recorded on the " $x$ " axis of an $x-y$ plotter and the load was recorded on the " $y$ " axis.

\subsubsection{Splitting Tensile Strength Test}

The splitting test was performed in accordance with ASTM C 496-71 [10] except that the loading rate was adjusted to be approximately $1 / 4$ of the expected maximum load per minute. Figure 3 shows the splitting test setup.

\subsubsection{Pull-out Bond Strength Test}

The testing procedure for the pull-out tests was essentially as described in ASTM C 234 [10] except that only the slip of the bar at the free end was measured. Figure 4 depicts the test setup. The load was applied in a screwtype testing machine at approximately $1 / 3$ of the expected maximum load per minute. Loading was continued until resistance to pull-out decreased.

The load and free-end slip were recorded on an $x-y$ recorder. The slip was measured with an LVDT which was mounted on a tripod held to the top of the specimen with hot-melt glue. Figure 5 shows a specimen under test.

It should be noted that the strength of the bond between reinforcing steel and concrete is a rather nebulous property in that there is no standard method for measurement of this property [11]. ASTM C 234-71 is a standard method used for comparing the "bond strengths" developed between a reinforcing steel bar and various concretes, but the values measured are not accepted as being design values [24]. For the purposes of this investigation it was assumed that a method based on ASTM C 234-71 can be used to determine the relative values of bond strength between No. 6 deformed bars and a concrete at the various ages and cure conditions. 


\subsubsection{Probe Penetration Test}

This procedure [9] is based on the depth of penetration of a special steel probe when driven into concrete with a precisely controlled powder charge. Empirically-obtained relationships are used to determine the compressive strength in terms of penetration measurements. The probes, powder charges ( 32 caliber blank cartridges), special driving gun, templates for guiding the probes, and a special measuring device are all part of a proprietory system available from the manufacturer. The measurements used are actually the converse of the depth-of-penetration, i.e., exposed length of the probe.

The manufacturer supplies a set of 5 calibration curves, each curve corresponding to a specific Mohs' hardness value ${ }^{3}$ for the coarse aggregate used in the concrete, by which penetration measurements can be converted to strength measurements. However, several investigators have observed $[11,12,13]$ that use of the manufacturer's calibration curve often results in grossly incorrect estimates of the compressive strength of concretes. These investigators recommend that the probe should be calibrated whenever the type of aggregate is changed.

For this investigation six probes were driven into each concrete slab (fig. 6) at each test age and the lengths of the probes extending above the concrete were measured using both a steel rule and the measuring device supplied by the manufacturer of the equipment (fig. 7). The Mohs' hardness value for the coarse aggregate was 5 .

A low-power setting of the gun was used for testing at ages 1, 2 and 3 days for all concrete slabs, and at the age of 5 days for the slab cured at $55^{\circ} \mathrm{F}$. All other tests were performed using the standard power setting.

\subsubsection{Rebound Hammer Test}

This procedure [9] is a widely used method of estimating the compressive strength of concrete based on the distance a steel plunger rebounds from the concrete surface after a precisely controlled impact.

The rebound hammer consists of a steel plunger and a tension spring in a tubular frame (fig. 8). When the head of the hammer is pushed against the concrete surface, the steel plunger is retracted against the force of the spring. When the head is completely retracted, the spring is automatically 3Mohs' scale is an arbitrary mineralogical scale of hardness in which a mineral will scratch other minerals that are lower on the scale (smaller hardness number) and will in turn be scratched by minerals higher on the scale. The Mohs' hardness number ranges from 1 for a talc to 10 for a diamond. 
released; the plunger is driven against the concrete and it rebounds. The rebound distance is indicated by a pointer on a scale that is graduated from 10 to 100 , and the rebound readings are termed $\mathrm{R}$-values.

Each hammer is furnished with a calibration chart supplied by the manufacturer, showing the relationship between compressive strength of concrete and rebound readings. This chart is based on data from tests conducted by the Swiss Federal Materials Testing and Experimental Institute. Each hammer, however, is known to vary slightly in performance.

\section{TEST RESULTS AND DISCUSSION}

\subsection{General}

The two objectives of this phase of the investigation were to evaluate the feasibility of determining all the pertinent mechanical properties at early ages for a concrete cured at various temperatures when (1) either one strength parameter is known or (2) results from NDE tests are known.

Currently, two methods are widely used to determine in-place strength of concrete. With one method, the "present" strength and stiffness of members are estimated to be some ratio of the design values. The ratio is taken from an assumed relationship between compressive strength and age of the concrete. With the other method, the "present" strength and stiffness of members are estimated from compressive strength measurements made on either site-cured cylinders or on cores taken from representative members. Other pertinent mechanical properties are estimated from these measured values.

The basic test data for this phase of the work are presented in tables 2 through 6 and figure 9. These tables give the test data for the five types of tests and figure 9 indicates the temperature of the concrete at various ages duxing the curing period.

The initial temperature of the concrete was $80^{\circ} \mathrm{F}\left(26.7^{\circ} \mathrm{C}\right)$ as indicated in figure 9. It should be noted that the temperature control for the $35^{\circ} \mathrm{F}$ $\left(1.7^{\circ} \mathrm{C}\right)$ chamber was erratic during the 17 to 30 day period. The sensitivity of the temperature measurements is estimated to be $\pm 1^{\circ} \mathrm{F}\left(0.6^{\circ} \mathrm{C}\right)$ for the $75^{\circ} \mathrm{F}\left(22.8^{\circ} \mathrm{C}\right)$ chamber and $\pm 2^{\circ} \mathrm{F}\left(1.1^{\circ} \mathrm{C}\right)$ for the other two chambers. Table 7 gives the mean temperature of the concrete for each relevant time interval during the curing period. The mean-temperature data was used in the following discussion of the maturity of concrete. 


\subsection{Maturity of Concrete}

It is known that the strength of concrete increases with time and that the rate of increase is greatly affected by temperature of cure. The combined effect of temperature and time (maturity) on the gain of the strength of concrete has been investigated by others $(12,13,14,15]$. The term "maturity," usually expressed in "degree-day (or hour)," may be defined as the sum of the product of the increment of age of cure and the difference between curing and some temperature below which no strength gain takes place. The definition can be written as:

$$
M=\Sigma\left(T-T_{0}\right) \Delta t
$$

where $T$ is temperature of the concrete at any time, $T_{0}$ is a datum temperature below which no strength gain of concrete takes place, and $\Delta t$ is the increment of time.

It has been shown from a series of compressive tests [12] that the strength of concrete remains constant at about $10^{\circ} \mathrm{F}\left(-12.2^{\circ} \mathrm{C}\right)$. Thus, equation (1) can be expressed as:

$$
M=\sum(T-10) \Delta t \quad\left(\text { where } T \text { is in }{ }^{\circ} \mathrm{F}\right) \text {. }
$$

The values of $M$ for each of the three curing conditions are listed in table 8 .

\subsection{Compressive Strength Test}

Figure 10 is a semi-log plot of the compressive strength data (average of 3 specimens) versus the maturity of the concrete. Individual regression lines obtained by the method of least squares are shown for each curing temperature. Pertinent statistical properties associated with each regression equation are given in table 9. Judging from the residual standard deviation of the individual regression lines, the compressive strength of the concrete can be related adequately to the maturity for each curing temperature. A good correlation among lines also suggests the possibility of expressing all the data, regardless of the curing condition, by a single regression line. This line is also shown in figure 10. While the residual standard deviation of the all-data line is somewhat greater than that of the individual lines ( 215 vs 121,163 and 108 in table 9), the data for all three cures fall reasonably well along the all-data line. 
In order to examine whether all the test points can be treated as one population, individual regression lines are compared with each other in terms of statistical quantities. First, a comparison is made of residual variances of the data about their respective regression lines (test of homogeneity of variances); next, the slopes of the individual regression lines are compared; and finally, relative positions of individual regression lines (or intercepts) are compared. 4

Homogeneity of the variances is tested by Bartlett's chi-square statistics [16]. The null hypothesis for the test is that individual variances are estimates of the same population variance. The computed value of chi-square statistic for the three lines was 1.20 with 2 degrees of freedom. When this value is compared with the theoretical chi-square distribution of 5.99 at a 5 percent significant level, the conclusion is to accept the null hypothesis. This is to say that the degree of dispersion of individual test points about their own regression line is about the same for all three lines.

Having established homogeneity of the residual variances, the slopes and intercepts are examined next. Any significant difference in individual slopes ( $b^{\prime} s$ ) and intercepts $\left(a^{\prime} s\right)$ is tested by comparing the ranges bound by the lower and upper limits of the slopes and intercepts of individual lines. The lower and upper limits are determined by computing confidence limits of the slopes and intercepts for a selected confidence coefficient. If these ranges overlap one another, it can be said that the slopes and intercepts do not differ significantly one another.

The lower and upper limits of the regression line $f_{c}^{\prime}=a+b$ log $M$ are expressed as:

$$
\begin{aligned}
& a-t s_{a^{\prime}} a+t s_{a} \\
& b-t s_{b^{\prime}} b+t s_{b}
\end{aligned}
$$

for the value of $t$ (t distribution) corresponding to the degrees of freedom and confidence coiefficient [17]. In the above expressions $s_{a}$ and $s_{b}$ are the standard errors of estimate of the regression coefficients a and $b$, respectively (see table 9). At a significance level of 0.05 (confidence coefficient 0.95 ) and with the degrees of freedom associated with $\bar{s}$, the lower and upper limits for the intercepts and slopes are computed and graphically depicted in figure 11. It is seen that the ranges of both the intercepts and slopes of

${ }^{4}$ The slopes and intercepts are compared here separately for simplicity and a more rigorous method for comparing several regression lines is given in reference [16]. 
the $73^{\circ} \mathrm{F}\left(22.8^{\circ} \mathrm{C}\right)$ and $55^{\circ} \mathrm{F}\left(12.8^{\circ} \mathrm{C}\right)$ lines show overlap, while those of the $35^{\circ} \mathrm{F}$ line do not overlap with those of the other two. This suggests that the trend of the compressive strength gain of the $35^{\circ} \mathrm{F}\left(1.7^{\circ} \mathrm{C}\right)$ cure specimens with time appears somewhat different from the other two. Since no definite conclusion can be drawn as to whether each regression line is significantly different from one another, there is no reason not to assume that the entire data are from a single population. The test of homogeneity of variance also supports the conclusion that the data from each individual group have the same characteristics. In light of the statistical evaluations, and the fact that the actual data fall fairly close to the all-data regression line (see fig. 10) the compressive strength of other concretes cured at different temperatures could be expressed in terms of maturity by a single line.

In the analysis of the other data presented in this report, the above described analytical procedures were followed to see whether the three regression lines from the three separate cures can be considered to be from a single population.

\subsection{Modulus of Elasticity}

The values of the modulus of elasticity listed in table 2 are the secant moduli of elasticity obtained at the stress levels $0.4 \mathrm{f}_{\mathrm{ci}}^{\prime}$ and $0.8 \mathrm{f}_{\mathrm{ci}}^{\prime}$ from stress-strain curves of the compressive test. Typical curves of the $35^{\circ} \mathrm{F}$ $\left(1.7^{\circ} \mathrm{C}\right)$-cure specimens are shown in figure 12 . The characteristics of the stress-strain curves of specimens cured at $73^{\circ} \mathrm{F}\left(22.8^{\circ} \mathrm{C}\right)$ and $55^{\circ} \mathrm{F}(12.8$ ${ }^{\circ} \mathrm{C}$ ) are similar to these curves.

In figure 13, the secant moduli are plotted against the maturity of the concrete. Regression lines are shown for each curing temperature. Pertinent statistical properties of these regression lines are listed in table 9. The procedures for statistical analyses as used in the case of the compressive strength were followed to see whether the data of three separate cures can be combined as a single group. Bartlett's chi-square statistic is 2.02 with 2 degrees of freedom. With the theoretical value of 5.99 at a 5 percent significant level, no significant difference in residual variances is expected among the three groups of the data. The lower and upper limits of the intercepts and slopes are depicted in figure 14. It is seen that the ranges of the slopes of the three curves all overlap one another, thereby indicating that the slopes of the curves are statistically about the same. However, in the case of the intercept, the range of the $35^{\circ} \mathrm{F}\left(1.7^{\circ} \mathrm{C}\right)$-cure line lies apart from the other two. This seems to suggest that dissimilarity of this 
group of data from the rest. However, the test on intercept being the weakest of the three tests, the hypothesis that the three regression lines are a family of lines of a single population cannot be rejected based solely on this test. Therefore, in this study, all three groups of data are treated as a single population.

\subsection{Splitting Tensile Strength Test}

A semi-log plot of the splitting tensile strength versus maturity is shown in figure 15. In general, the test points fall reasonably close to the all-data regression line. The dispersion of the data relative to the individual regression lines is about the same as that noted in the compressive strength versus maturity. The coefficients of determination are $0.97,0.98$ and 0.99 for the three regression lines, indicating a strong correlation between the two variables. This clearly shows that the splitting tensile strength can also be related to maturity as well as the compressive strength.

From figure 15 it is seen that the all-data line fits well through the entire data with a coefficient of determination of 0.95 . As in the previous cases, homogeneity of the residual variances, the intercepts and the slopes of the three individual lines are compared to see whether the entire data, irrespective of curing temperature, can be treated collectively as a single group and represented by a single line. The analysis gives a Bartlett's chi-square of 5.46 (theoretical $x^{2}=5.99$ at $\alpha=0.05$ ) with 2 degrees of freedom. As before, this test shows no significant difference in the three residual variances of the data of each temperature group about its own regression line, this confirming homogeneity of the data.

The ranges of the intercepts and slopes are shown in figure 16. The relative positions of the range of the limits show that only the intercept of the $35^{\circ} \mathrm{F}\left(1.7^{\circ} \mathrm{C}\right)$-cure line does not overlap with the others. This can be attributed to a wider dispersal of the $35^{\circ} \mathrm{F}\left(1.7{ }^{\circ} \mathrm{C}\right)$-cure data compared with the others. These analyses, together with the actual distribution of the data shown in figure 15, indicate that the individual regression lines do not differ significantly one from the other and that the entire data could be represented by a single curve.

\section{6 Pull-out Bond Strength Tests}

The pull-out test does not provide a realistic bond strength which can be used in design of flexural members. This is due primarily to the different 
crack patterns between those developed in pull-out specimens and those in flexural specimens [25]. However, past research has shown that pull-out tests can be used satisfactorily to determine relative bond strengths $[19,20]$. Accordingly, pull-out tests were carried out in this investigation because the purpose of the investigation was to determine relative bond strength with respect to the 28 -day strength.

A semi-log plot of the maximum pull-out loads versus maturity is shown in figure 17. In this figure those maximum loads governed by the yielding of the bar are shown as solid points. In the regression analyses these points are not included. Except for these solid points, the pull-out loads increased with maturity. As in other cases, the residual variances, the intercepts and the slopes of the individual lines are compared to determine if all the data can be treated as a single group.

A computed Bartlett's chi-square value is 1.17 (theoretical $x^{2}=5.99$ at $\alpha=0.05)$, with 2 degrees of freedom, indicating that the individual residual variances are not significantly different from one another. The lower and upper limits of the intercepts and slopes are shown in figure 18.

It is seen that the ranges of the intercept (a) and slope (b) of the $35^{\circ} \mathrm{F}\left(1.7^{\circ} \mathrm{C}\right)$-cure 1 ine do not overlap with the ranges of the $55^{\circ} \mathrm{F}\left(12.8{ }^{\circ} \mathrm{C}\right)$ - and $73^{\circ} \mathrm{F}\left(22.8^{\circ} \mathrm{C}\right)$-cure lines. This disparity is also seen in figure 17 where the $35^{\circ} \mathrm{F}\left(1.7{ }^{\circ} \mathrm{C}\right)$-cure line has a steeper slope than the other two. Because the deviation of the $35^{\circ} \mathrm{F}\left(1.7^{\circ} \mathrm{C}\right)$ curve from the others could result from one or two extreme data points, the disparity of the intercept and slope alone could not be used as a reason for discriminating against the data of specimens cured at $35^{\circ} \mathrm{F}\left(1.7^{\circ} \mathrm{C}\right)$. More data are needed to reach a statistically valid conclusion. However, with narrowly dispersed data along the all-data line, together with a relatively small chi-square value in Bartlett's test, all the pull-out data are treated in this study as belonging to a single population.

\subsection{Rate of Strength and Modulus Gain with Maturity}

One of the purposes of this experimental study was to determine relative relationships between several important strength properties and the elastic modulus of a concrete at early ages. Inasmuch as the 28-day values of these mechanical properties obtained from a concrete cured at $73^{\circ} \mathrm{F}\left(22.8^{\circ} \mathrm{C}\right)$ have been accepted as a standard reference value, the compressive, splitting tensile and pull-out strengths and the moduli are normalized by dividing by their 
respective 28 -day value from $73^{\circ} \mathrm{F}\left(22.8^{\circ} \mathrm{C}\right)$ cure. These normalized values, when plotted against the maturity of concrete, can be used to compare the rate of increase in these strengths and the modulus with respect to the 28-day values. The least-square curves of the normalized plots for each of these strength properties and the modulus are shown in figure 19. Because the normalization was made with values obtained from the regression lines, the normalized curves do not pass through 1.0 at a maturity of 1764 . For the concrete investigated in this study, the rate of increase in the splitting tensile strength is about the same as that of the compressive strength, whereas the rate of increase in the pull-out strength and the modulus are slightly greater than that of the compressive strength at early ages.

\subsection{Non-Destructive Tests}

\subsubsection{Probe Penetration}

The averages, standard deviations, and coefficients of variation for the probe measurements are given in table 5. The average exposed lengths of probe were measured at 1 and 2 days using the mechanical averaging device (average of three probes). This averaging device is convenient to use, but it was desirable to determine the variation between individual penetrations. Thereafter, the exposed lengths of each probe were measured with a steel rule. The coefficient of variation for a set of either 5 or 6 measurements ranged from 2.6 to 13.7 percent, averaging 8.0 percent. Similar large variabilities in probe test results have been previously reported by Arni [21] and Malhotra [22]. Gaynor concluded [23] that the heterogeneity of concrete (with hardened cement past, mortar matrix and course aggregate phases) limits the accuracy of the probe system.

For each set of measurements, the compressive strength obtained from the cylinder test is plotted in figure 20 versus the strength predicted by the conversion chart provided by the probe manufacturer for the Mohs' hardness of 5. The solid points correspond to results using a low-charge setting and the open points correspond to results using the standard charge setting. Because the charts for the standard setting do not provide compressive strengths for low values of exposed probe length, 5- and 7-day readings of the $73^{\circ} \mathrm{F}$ cure specimens, 7- and 14-day readings of the $55^{\circ} \mathrm{F}$ cure specimens, 7, and 14 day readings of the $35^{\circ} \mathrm{F}$ cure specimens are not included in the figure.

It is clearly evident from the figure that the probe readings overestimate considerably the cylinder strength. The difference between the strength predicted by the probe test and the cylinder test is greater at the 
upper end of the chart for the low charge and the lower end of the chart for the standard charge. For Mohs' hardness value of 5, the compressive strength from the chart for the low charge ranges from $450 \mathrm{psi}$ ( $3.10 \mathrm{MPa}$ ) to $4825 \mathrm{psi}$ (29.55 MPa) and for the standard charge it ranges from 3050 psi (21.03 MPa) to $10,000 \mathrm{psi}(68.95 \mathrm{MPa})$. Based on this investigation, it is reasonable to conclude that the probe method cannot be applied readily to all ages and types of concrete using the manufacturer's conversion charts to estimate the compressive strength.

\subsubsection{Rebound Hammer}

Fifteen rebound numbers were taken during each set of measurements and only the values above the minumum measurable level of 10 were used in calculating the averages, the standard deviations, and the coefficients of variation (table 6). In three instances, because of the large number of rebound values below 10, the averages were considered to be less than 10. The average compressive strength of cylinders cured at $55^{\circ} \mathrm{F}\left(12.8^{\circ} \mathrm{C}\right)$ and $35^{\circ} \mathrm{F}\left(1.7^{\circ} \mathrm{C}\right)$ ranged from $980 \mathrm{psi}(6.76 \mathrm{MPa})$ to $1480 \mathrm{psi}(10.21 \mathrm{MPa}$ ) for the first two days. Thus, for concretes having a compressive strength less than 1500 psi (10.34 $\mathrm{MPa})$, rebound readings cannot be taken with certainty. Furthermore, for rebound readings less than 20 which is less than the lower $20 \%$ of the full scale of 100 , the precision, thus the validity, of rebound measurements is questionable. In this investigation the coefficient of variation for a set of 15 measurements ranged from 6.2 to 20.5 percent. With these observations, no attempt is made to correlate the rebound readings to the compressive strength obtained from the cylinder test.

\section{SUMMARY AND CONCLUSIONS}

The gain in mechanical properties of a concrete with time was investigated in this study. In addition, two widely known non-destructive evaluation methods were examined as to their applicability in determination of the compressive strength of concrete at early ages. The test specimens cured at three temperatures were tested following three destructive and two nondestructive test procedures. The gain of splitting tensile and relative bond strengths and of the elastic modulus are compared with that of compressive strength. The compressive strength obtained from non-destructive evaluations are compared with the cylinder strength. 
The following conclusions can be drawn from the test results:

(1) Analysis of the test data shows that the compressive strength of concrete can be related to the maturity expressed in terms of concrete temperature and age of cure. Both a high value of the coefficient of determination of the all-data regression line and homogeneity of the residual variances of the individual regression lines indicate that the compressive strength data of a concrete cured at different temperatures could be treated collectively as a single group when expressed in terms of maturity.

(2) When related to maturity, the elastic modulus data and the splitting tensile strength data of specimens cured at various temperatures could be treated as being from single groups.

(3) The analysis of the results shows that the pull-out strength, when not governed by the yielding of the bar, could be expressed in terms of maturity, thus allowing the specimens cured at various temperatures to be treated as a single group. However, further investigation should be made with specimens cured at low temperatures to support the observation that the $35^{\circ} \mathrm{F}\left(1.7^{\circ} \mathrm{C}\right)$-cure data deviated from the others.

(4) At early ages, the rate of increase in the splitting tensile strength is about the same as that of the compressive strength, whereas the rate of increase in the pull-out strength and the modulus are slightly greater than that of the compressive strength.

(5) It was found that for the concrete used in this investigation, the probe method did not estimate correctly the compressive strength when the estimation is made using the conversion charts provided by the manufacturer. Further tests are needed to ascertain the applicability of the probe method for estimation of the early strength of concrete.

(6) Because of low rebound readings for concrete at early ages (below 20 percent of a full scale of 100), a reliable estimation of the compressive strength could not be made using the rebound hammer. 


\section{REFERENCES}

[1] "The Building Collapse at 2000 Commonwealth Avenue, Boston, Massachusetts," Report of the Mayor's Investigating Commission, City of Boston, Massachusetts, 1971 .

[2] Leyendecker, E. V. and Fattal, S. G., "Investigation of the Skyline Plaza Collapse in Fairfax County, Virginia," NBSIR 73-222, National Bureau of Standards, Washington, D.C., 1973.

[3] Klieger, P., "Effect of Mixing and Curing Temperature on Concrete Strength," Journal of the American Concrete Institute, Vol. 54, American Concrete Institute, Detroit, Michigan, June 1958.

[4] Price, W. H., "Factors Influencing Concrete Strength," Journal of the American Concrete Institute, Vol. 47, American Concrete Institute, Detroit, Michigan, February 1951.

[5] Grundy, P. and Kabaila, A., "Construction Loads on Slabs With Shored Formwork in Multistory Buildings," Journal of the American Concrete Institute, Vol. 60, American Concrete Institute, Detroit, Michigan December 1963.

[6] Agaswal, R. K. and Gardner, N. J., "Form and Shore Requirements for Multistory Flat Slab Type Buildings," Journal of the American Concrete Institute, Vol. 71, American Concrete Institute, Detroit, Michigan, November 1974 .

[7] Bloem, D. I., "Concrete Strength Measurements - Core Versus Cylinders," Proceedings of the American Society for Testing Material, Vol. 65, Philadelphia, Pa., 1965.

[8] Bloem, D. L., "Concrete Strength in Structures," Journal of the American Concrete Institute, Vol. 65, American Concrete Institute, Detroit, Michigan, March 1968.

[9] Clifton, J. R., "Nondestructive Tests to Determine Concrete Strength A Status Report," NBSIR 75-729, National Bureau of Standards, Washington, D.C., 1975.

[10] 1974 Annual Book of ASTM Standards, Part 14, American Society of Testing and Materials, Philadelphia, Pa., 19103. 
[11] "Bond Stress - The State of the Art," ACL Committee 408, American Concrete Institute, Detroit, Michigan, November 1966.

[12] Plowman, J. M., "Maturity and the Strength of Concrete," Magazine of Concrete Research Vol. 8, No. 22, pp. 13-22, London, 1956.

[13] Sadgrove, B. M., "Prediction of Strength Development in Concrete Structures," A paper presented at the 54 th Annual Meeting of the Transportation Research Board, Washington, D.C., 1975.

[14] Hudson, S. B. and Steele, G. W., "Prediction of Potential Strength of Concrete from the Results of Early Tests," Highway Research Record, No. 370, Highway Research Board, 1971.

[15] Hudson, S. B. and Steele, G. W., "Developments in the Prediction of Potential Strength of Concrete froin the Results of Early Test," A paper presented at the 54 th Annual Meeting of the Transportation Research Board, Washington, D.C., 1975.

[16] Snedecor, G. W. and Cochran, W. G., "Statistical Methods," 6th edition, The Iowa State University Press, Ames, Iowa, 1967.

[17] Ku, H. H., "Statistical Concepts in Metrology," National Bureau of Standards special Publication 300, Vol. 1, U.S. Government Printing Office, Washington, D.C. 20402, February 1969.

[18] ACI 318-71, "Building Code Requirements for Reinforced Concrete," American Concrete Institute, Detroit, Michigan, 1971.

[19] Bresler, B., editor, "Reinforced Concrete Engineering, Vol. I. Materials, Structural Elements Safety, Chapter 4," John Wiley \& Sons, Inc., New York, 1974.

[20] Ferguson, P. M., "Reinforced Concrete Fundamentals, Chapter 5," John Wiley \& Sons, Inc., New York, 1971.

[21] Arni, H. T., "Impact and Penetration Tests of Portland Cement Concrete in Nondestructive Testing of Concrete," Highway Research Record 378, pp. 55-67, Highway Research Board, 1972.

[22] Malholtra, V. M. and Painter, K., "Evaluation of the Windsor Probe Test for Estimating Compressive Strength of Concrete," Mines Branch 
Investigation Report IR 71-50, Ottawa, Canada, 1971.

[23] Gaynor, R. D., "In-Place Strength of Concrete - A Comparison of Two Test Systems," National Ready-Mix Concrete Association Technical Information Letter No. 272, 1969.

[24] Watstein, D., "Bond with Reinforcing Steel," ASTM Special Technical Publication No. 169-A, American Society for Testing and Materials, Philadelphia, Pa., 1966.

[25] Mathey R. G. and Watstein, D., "Investigation of Bond in Beam and PullOut Specimens with High-Yield-Strength Deformed Bars," Journal of the American Concrete Institute, Vol. 32, Americal Concrete Institute, Detroit, Michigan, March, 1961. 
Table 1. Distribution of Test Specimens to Three Curing Conditions

\begin{tabular}{|c|c|c|c|}
\hline Type of Specimen & $\begin{array}{l}73^{\circ} \mathrm{F} \text { Cure } \\
\left(22.8^{\circ} \mathrm{C}\right)\end{array}$ & $\begin{array}{r}55^{\circ} \mathrm{F} \text { Cure } \\
\left(12.8^{\circ} \mathrm{C}\right)\end{array}$ & $\begin{array}{c}35^{\circ} \mathrm{F} \text { Cure } \\
\left(1.7^{\circ} \mathrm{C}\right)\end{array}$ \\
\hline $\begin{array}{l}\text { Compressive Test } \\
\text { ( } 6 \text { in } x 12 \text { in cyl.) } \\
\text { Splitting Tensile } \\
\text { Test ( } 6 \text { in } x 12 \text { in } \\
\text { cyl.) } \\
\text { Pull-out Test } \\
\text { (6 in } 8 \text { in cyl.) } \\
\text { NDE slab } \\
\text { (3 ft } x 5 \text { ft } x \\
5-1 / 2 \text { in) }\end{array}$ & 24 & $\begin{array}{l}30 \\
1\end{array}$ & $\begin{array}{l}36 \\
36\end{array}$ \\
\hline
\end{tabular}

1 inch $=25.40 \mathrm{~mm}$

1 foot $=304.80 \mathrm{~mm}$ 
Table 2. Compressive Strength Test Results /

\begin{tabular}{|c|c|c|c|c|c|c|c|c|c|c|}
\hline \multirow{2}{*}{ Age } & \multirow{2}{*}{$\begin{array}{l}\text { Specimen } \\
\text { Number }\end{array}$} & \multicolumn{3}{|c|}{ Cuxed at $73^{\circ} \mathrm{F}\left(22.8^{\circ} \mathrm{C}\right)$} & \multicolumn{3}{|c|}{ Cured at $55^{\circ} \mathrm{F} \quad\left(12.8^{\circ} \mathrm{C}\right)$} & \multicolumn{3}{|c|}{ Cured at $35^{\circ} \mathrm{F} \quad\left(1.7^{\circ} \mathrm{C}\right)$} \\
\hline & & $f_{c i}^{\prime}$ & $\mathrm{E}_{\mathrm{s}}{ }^{\mathrm{Q} .4 f_{c i}^{\prime}}$ & $\mathrm{E}_{s}{ }^{a .8 f_{c i}^{\prime}}$ & $f_{c i}^{\prime}$ & $\mathrm{E}_{s}{ }^{\Theta .4 f_{c i}^{\prime}}$ & $\mathrm{E}_{\mathrm{s}} \mathrm{a} .8 \mathrm{f}_{\mathrm{ci}}^{\prime}$ & $f_{c i}^{\prime}$ & $E_{s} e .4 f_{c i}^{\prime}$ & $E_{s} 9.8 f_{c i}^{\prime}$ \\
\hline days & & $\underset{(\mathrm{MPa})}{p s i}$ & $\begin{array}{l}10^{6} \mathrm{psi} \\
(\mathrm{GPa})\end{array}$ & $\begin{array}{r}10^{6} \mathrm{psi} \\
(\mathrm{GPa})\end{array}$ & $\underset{\text { (MPa) }}{\text { psi }}$ & $\begin{array}{r}10^{6} \mathrm{psi} \\
(\mathrm{GPa})\end{array}$ & $\begin{array}{l}10^{6} \mathrm{psi} \\
(\mathrm{GPa})\end{array}$ & $\underset{\text { (MPa) }}{\text { Psi }}$ & $\begin{array}{l}10^{6} \mathrm{psi} \\
\text { (GPa) }\end{array}$ & $\begin{array}{l}10^{6} \mathrm{psi} \\
(\mathrm{GPa})\end{array}$ \\
\hline \multirow[t]{4}{*}{1} & 1 & 1350 & 2.06 & 1.56 & 1170 & 1.96 & 1.36 & 955 & 1.78 & 1.19 \\
\hline & 2 & 1420 & 2.27 & 1.61 & 1180 & 2.03 & 1.46 & 944 & 1.49 & .94 \\
\hline & 3 & 1220 & 2.64 & 2.01 & 1200 & 1.91 & 1.36 & 1040 & 1.63 & $\$ 99$ \\
\hline & $\begin{array}{l}\text { Average } \\
\text { (C.v.., })\end{array}$ & $\begin{array}{c}1330 \\
(9.17) \\
(8) \\
\end{array}$ & $\begin{array}{c}2.32 \\
(16.00)\end{array}$ & $(11.73$ & $\begin{array}{c}1180 \\
(1.14) \\
(1)\end{array}$ & $(13.58)$ & $\begin{array}{c}1.39 \\
(9.58)\end{array}$ & $\begin{array}{c}980 \\
(6.76) \\
(5)\end{array}$ & $(11.63)$ & $\left(\begin{array}{l}1.04 \\
7.17\end{array}\right)$ \\
\hline \multirow[t]{4}{*}{2} & 1 & 1910 & 2.89 & 2.32 & 1470 & 2.67 & 1.70 & 1250 & 1.67 & 1.11 \\
\hline & 2 & 1870 & 3.25 & 2.50 & 1520 & 2.26 & 1.70 & 1280 & 1.83 & 1.13 \\
\hline & 3 & 2200 & 2.95 & 2.20 & 1450 & 2.49 & 1.82 & 1260 & 1.67 & 1.11 \\
\hline & $\begin{array}{l}\text { Average } \\
(C, v,, 8)\end{array}$ & $\begin{array}{c}1990 \\
(13.72) \\
(9)^{2}\end{array}$ & $\begin{array}{c}3.03 \\
(20.89)\end{array}$ & $\begin{array}{c}2.34 \\
(16.13)\end{array}$ & $\begin{array}{c}1480 \\
(10.20) \\
(2)\end{array}$ & $\left(\begin{array}{c}2.47 \\
(17.03)\end{array}\right.$ & $\left(\begin{array}{c}1.74 \\
(12.00)\end{array}\right.$ & $\begin{array}{r}1260 \\
(8.69) \\
(1)\end{array}$ & $\frac{1.72}{(11.86)}$ & $\left(\frac{1}{7.72}\right)$ \\
\hline \multirow[t]{4}{*}{3} & 1 & 2210 & 3.51 & 2.65 & 1780 & 2.69 & 2.04 & 1400 & 2.09 & 1.58 \\
\hline & 2 & 2220 & 3.61 & 2.65 & 1680 & 2.83 & 2.17 & 1340 & 2.12 & 1.66 \\
\hline & 3 & 2150 & 2.72 & 2.25 & 1770 & 2.55 & 2.00 & 1420 & 2.09 & 1.62 \\
\hline & $\begin{array}{l}\text { Average } \\
\text { (C.v.,8) }\end{array}$ & $\begin{array}{c}2190 \\
(15.10) \\
(2)\end{array}$ & $\left(\begin{array}{c}3.28 \\
(22.61)\end{array}\right.$ & $(17.52)$ & $\begin{array}{c}1740 \\
(12.00) \\
(3)\end{array}$ & $\begin{array}{c}2.69 \\
(18.99)\end{array}$ & $\begin{array}{c}2.07 \\
(14.27)\end{array}$ & $\begin{array}{c}1390 \\
(9.58) \\
(3)\end{array}$ & $\begin{array}{l}2.10 \\
(14.48)\end{array}$ & $(11.17)$ \\
\hline \multirow[t]{4}{*}{5} & 1 & 2460 & 3.69 & 2.86 & 2000 & 2.99 & 2.26 & 1880 & 2.16 & 1.56 \\
\hline & 2 & 2480 & 3.93 & 2.90 & 1950 & 2.89 & 2.28 & 1710 & 2.32 & 1.70 \\
\hline & 3 & 2710 & 3.66 & 2.84 & 1830 & 3.40 & 2.75 & 1840 & 2.64 & 2.08 \\
\hline & $\begin{array}{l}\text { Average } \\
\text { (C.,..8) }\end{array}$ & $\begin{array}{c}2590 \\
(17.86) \\
(5) \\
\end{array}$ & $\begin{array}{c}3.76 \\
(25.92)\end{array}$ & $(19.79)$ & $\begin{array}{c}1930 \\
(13.31) \\
(4)\end{array}$ & $\stackrel{3.09}{(2 i .30)}$ & $\begin{array}{c}2.43 \\
(16.75)\end{array}$ & $\begin{array}{c}1810 \\
(12.48) \\
(5)\end{array}$ & $\begin{array}{l}2.37 \\
(16.34)\end{array}$ & $\begin{array}{c}1.78 \\
(12.27)\end{array}$ \\
\hline \multirow[t]{4}{*}{7} & 1 & 2850 & 3.62 & 2.78 & 2510 & 3.23 & 2.63 & 2180 & 3.29 & 2.16 \\
\hline & 2 & 2930 & 3.81 & 3.05 & 2640 & 3.47 & 3.02 & 2200 & 2.55 & 1.93 \\
\hline & 3 & 2890 & 3.55 & 2.78 & 2550 & 3.23 & 2.56 & 2170 & 2.80 & 2.08 \\
\hline & $\begin{array}{l}\text { Average } \\
(\mathrm{C} . \mathrm{V} ., \mathrm{s})\end{array}$ & $\begin{array}{c}2890 \\
\left(199^{3)}\right. \\
(1)^{3}\end{array}$ & $\begin{array}{c}3.66 \\
(25.23)\end{array}$ & $\begin{array}{c}2.87 \\
(19.79)\end{array}$ & $\begin{array}{c}2570 \\
(17(72) \\
(3)\end{array}$ & $\begin{array}{c}3.31 \\
(22.82)\end{array}$ & $\begin{array}{c}2.74 \\
(18.89)\end{array}$ & $\begin{array}{c}2180 \\
\left(150^{03}\right) \\
(1)^{2}\end{array}$ & $\begin{array}{c}2.88 \\
(19.86)\end{array}$ & $\begin{array}{c}2.06 \\
(14.20)\end{array}$ \\
\hline \multirow[t]{4}{*}{14} & 1 & 3160 & 3.59 & 3.11 & 2590 & 3.42 & 3.03 & 2700 & 3.09 & 2.48 \\
\hline & 2 & 3320 & 3.71 & 3.15 & 2720 & 3.54 & 3.02 & 2810 & 3.22 & 2.49 \\
\hline & 3 & 3190 & 3.65 & 3.16 & 2520 & 3.62 & 3.03 & 2640 & 3.23 & 2.52 \\
\hline & $\begin{array}{l}\text { Average } \\
\text { (c.v., \&) }\end{array}$ & $\begin{array}{r}3230 \\
(22.27) \\
(3)\end{array}$ & $\begin{array}{l}3.65 \\
(25.17)\end{array}$ & $\begin{array}{c}3.14 \\
(21.69)\end{array}$ & $\begin{array}{c}2610 \\
(18.000) \\
(4)\end{array}$ & $\begin{array}{c}3.53 \\
(24.34)\end{array}$ & $(20.89)$ & $\begin{array}{c}2720 \\
(187.54) \\
(3)\end{array}$ & $\begin{array}{c}3.18 \\
(21.93)\end{array}$ & $\begin{array}{c}2.50 \\
(17.24)\end{array}$ \\
\hline \multirow[t]{4}{*}{21} & 1 & 3210 & 4.04 & 3.37 & 2850 & 3.68 & 2.73 & 2990 & 3.42 & 2.62 \\
\hline & 2 & 3270 & 3.71 & 3.12 & 2700 & 3.40 & 2.72 & 3060 & 3.42 & 2.74 \\
\hline & 3 & 3500 & 3.97 & 3.48 & 2770 & 4.16 & 3.22 & 3020 & 3.68 & 2.87 \\
\hline & $\begin{array}{l}\text { Average } \\
\text { (c.v.,8) }\end{array}$ & $\begin{array}{c}3330 \\
(22.96) \\
(5)\end{array}$ & $\left(\begin{array}{l}3.91 \\
(26.96)\end{array}\right.$ & $(22.27)$ & $\begin{array}{c}2770 \\
(19.10) \\
(3)\end{array}$ & $\begin{array}{c}3.75 \\
(25.86)\end{array}$ & $\begin{array}{c}2.89 \\
(19.93)\end{array}$ & $\begin{array}{c}3020 \\
(120.82) \\
(1)\end{array}$ & $\begin{array}{c}3.51 \\
(24.20)\end{array}$ & $\begin{array}{c}2.74 \\
(18.89)\end{array}$ \\
\hline \multirow[t]{4}{*}{28} & 1 & 3560 & 4.27 & 3.54 & 2790 & 2.93 & 3.14 & 3460 & 3.73 & 3.19 \\
\hline & 2 & 3590 & 4.35 & 3.54 & 2810 & 4.70 & 3.36 & 3380 & 3.99 & 3.32 \\
\hline & 3 & 3520 & 4.82 & 3.91 & 2950 & 4.02 & 3.19 & 3360 & 3.39 & 2.98 \\
\hline & $\begin{array}{l}\text { Average } \\
\text { (c.v., })\end{array}$ & $\begin{array}{c}3560 \\
\left(24{ }^{55)}\right. \\
(1) \\
\end{array}$ & $\begin{array}{c}4.48 \\
(30.89)\end{array}$ & $\begin{array}{c}3.66 \\
(25.23)\end{array}$ & $\begin{array}{c}2850 \\
(19.65) \\
(3) \\
\end{array}$ & $\begin{array}{c}3.88 \\
(26.75)\end{array}$ & $\begin{array}{c}3.23 \\
(22.27)\end{array}$ & $\begin{array}{c}3400 \\
(23.44) \\
(2) \\
\end{array}$ & $\begin{array}{c}3.70 \\
(25.51)\end{array}$ & $\begin{array}{c}3.16 \\
(21.79)\end{array}$ \\
\hline \multirow[t]{4}{*}{42} & 1 & - & - & - & 3300 & 4.04 & 3.40 & 3610 & 4.25 & 3.62 \\
\hline & 2 & - & - & - & 3420 & 4.39 & 3.73 & 3380 & 3.81 & 3.14 \\
\hline & 3 & - & - & - & 3440 & 4.61 & 3.73 & 3250 & 3.73 & 3.04 \\
\hline & $\begin{array}{l}\text { Average } \\
(C . v \ldots, 8)\end{array}$ & - & - & - & $\begin{array}{c}3390 \\
(23.37) \\
(2)\end{array}$ & $\begin{array}{c}4.35 \\
(29.99)\end{array}$ & $\begin{array}{c}3.62 \\
(24.96)\end{array}$ & $\begin{array}{c}3410 \\
(23.51) \\
(5)\end{array}$ & $\begin{array}{c}3.93 \\
(27.10)\end{array}$ & $\begin{array}{c}3.27 \\
(22.55)\end{array}$ \\
\hline
\end{tabular}

a/ $f_{c i}^{\prime}$ is the compressive strength at each age. $E_{s}$ is the secant modulus of elasticity taken from individual stress-strain curves. psi $=1.1 \mathrm{bf} / \mathrm{in}^{2}=6895$ pascal $\quad \mathrm{C} . \mathrm{v}_{\mathrm{l}}=$ = coefficient of variation 
Table 3. Splitting Tensile strength Test Results $a /$

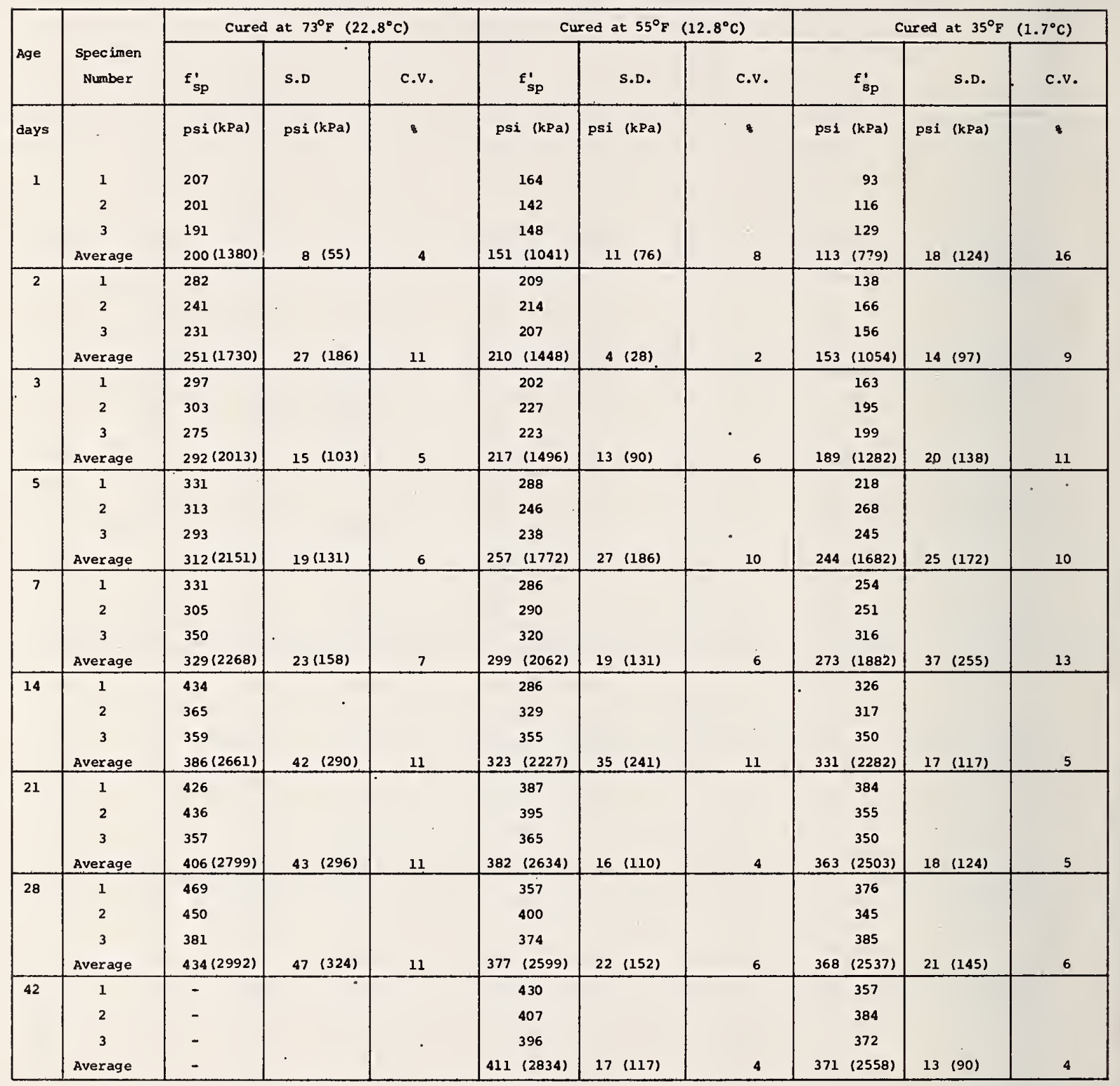

a/Splitting Tensile strength $\left(f_{s p}^{\prime}\right)=\frac{2 P}{\pi D L} ;$ where $P=$ load at splitting, $D=$ diameter of specinen $(6$ in $=15 \mathrm{~cm})$ and $\mathrm{L}=1$ length of specimen $(12$ in $\approx 30 \mathrm{~cm}), \mathrm{psi}=1 \mathrm{lbf} / \mathrm{in}^{2}=6895$ pascal. S.D. = Standard deviation and C.v. $=$ Coefficient of variation. 
Table 4. Pull-Out Bond Strength Test Results

\begin{tabular}{|c|c|c|c|c|c|c|c|c|c|c|}
\hline \multirow[b]{2}{*}{ Age } & \multirow[b]{2}{*}{$\begin{array}{l}\text { specimen } \\
\text { Number }\end{array}$} & \multicolumn{3}{|c|}{ Cured at $73^{\circ} \mathrm{F}\left(22.8^{\circ} \mathrm{C}\right)$} & \multicolumn{3}{|c|}{ Cured at $55^{\circ} \mathrm{F} \quad\left(12.8^{\circ} \mathrm{C}\right)$} & \multicolumn{3}{|c|}{ Cured at $35^{\circ} \mathrm{F} \quad\left(1.7^{\circ} \mathrm{C}\right)$} \\
\hline & & $\begin{array}{c}\mathrm{p} \\
\text { Maximum }\end{array}$ & $\begin{array}{c}\text { p slip } \\
\text { of } .001 \text { in }\end{array}$ & $\begin{array}{l}\text { p e slip } \\
\text { of .002 in }\end{array}$ & $\begin{array}{c}p \\
\text { Maximum }\end{array}$ & $\begin{array}{l}\text { P @ slip } \\
\text { of .001 in }\end{array}$ & $\begin{array}{c}\text { p slip } \\
\text { of } .002 \text { in }\end{array}$ & $\begin{array}{c}P \\
\text { Maximum }\end{array}$ & $\begin{array}{l}\text { p S slip } \\
\text { of .001 in }\end{array}$ & $\begin{array}{l}\text { p@slip } \\
\text { of .002 in }\end{array}$ \\
\hline days & $\begin{array}{c}1 \\
2 \\
3 \\
\text { Average } \\
(\mathrm{C} . \mathrm{V} ., 8)\end{array}$ & $\begin{array}{c}\text { Kip } \\
(\mathrm{kN}) \\
15.00 \\
14.15 \\
14.60 \\
\begin{array}{c}14.58 \\
(64.85) \\
(3)\end{array} \\
\end{array}$ & $\begin{array}{c}\text { Kip } \\
\text { (kN) } \\
7.1 \\
4.6 \\
6.3 \\
6.0 \\
(26.69)\end{array}$ & $\begin{array}{c}\text { Kip } \\
(\mathrm{kN}) \\
8.5 \\
6.5 \\
8.5 \\
7.8 \\
(34.69)\end{array}$ & $\begin{array}{c}\text { Kip } \\
(\mathrm{kN}) \\
10.50 \\
11.30 \\
12.05 \\
11.28 \\
(50,17)\end{array}$ & $\begin{array}{c}\text { Kip } \\
(\mathrm{kN}) \\
5.3 \\
4.9 \\
6.1 \\
5.4 \\
(24.02)\end{array}$ & $\begin{array}{c}\text { kip } \\
(\mathrm{kN}) \\
6.3 \\
5.9 \\
7.6 \\
6.6 \\
(29.36)\end{array}$ & $\begin{array}{c}\text { Kip } \\
(\mathrm{kN}) \\
8.53 \\
8.43 \\
9.58 \\
8.85 \\
(397)^{36)}\end{array}$ & $\begin{array}{c}\text { Kip } \\
(\mathrm{kN}) \\
3.7 \\
4.8 \\
3.9 \\
4.1 \\
(18.24)\end{array}$ & $\begin{array}{c}\text { Kip } \\
(\mathrm{kN}) \\
4.5 \\
5.7 \\
4.9 \\
5.0 \\
(22.24)\end{array}$ \\
\hline 2 & $\begin{array}{c}1 \\
2 \\
3 \\
\text { Average } \\
\text { (c.v., s) }\end{array}$ & $\begin{array}{c}19.20 \\
15.65 \\
18.20 \\
17.68 \\
(78.64) \\
(10)\end{array}$ & $\begin{array}{c}8.9 \\
6.5 \\
7.0 \\
7.5 \\
(33.36)\end{array}$ & $\begin{array}{c}10.6 \\
8.4 \\
8.9 \\
9.3 \\
(41.37)\end{array}$ & $\begin{array}{c}13.45 \\
14.10 \\
13.90 \\
\begin{array}{c}13.82 \\
(61.47) \\
(2)\end{array}\end{array}$ & $\begin{array}{c}6.2 \\
7.6 \\
7.6 \\
7.1 \\
(31.58)\end{array}$ & $\begin{array}{c}7.3 \\
8.9 \\
8.6 \\
8.3 \\
(36.92)\end{array}$ & $\begin{array}{c}12.45 \\
12.85 \\
12.30 \\
12.53 \\
(55.73)\end{array}$ & $\begin{array}{c}5.5 \\
6.0 \\
- \\
5.8 \\
(25.80)\end{array}$ & $\begin{array}{c}6.7 \\
7.0 \\
- \\
6.9 \\
(30.69)\end{array}$ \\
\hline 3 & $\begin{array}{c}1 \\
2 \\
3 \\
\text { Average } \\
\text { (c.v..8) } \\
\end{array}$ & $\begin{array}{c}19.15 \\
20.70 \\
20.50 \\
20.12 \\
(89.49) \\
(4) \\
\end{array}$ & $\begin{array}{c}7.8 \\
9.2 \\
8.7 \\
8.6 \\
(38.25)\end{array}$ & $\begin{array}{l}10.0 \\
11.5 \\
11.0 \\
10.8 \\
(48.04)\end{array}$ & $\begin{array}{c}17.35 \\
16.65 \\
17.35 \\
17.12 \\
(76.15) \\
(2)\end{array}$ & $\begin{array}{c}9.2 \\
11.1 \\
9.6 \\
10.0 \\
(44.48)\end{array}$ & $\begin{array}{l}10.8 \\
12.0 \\
11.2 \\
11.3 \\
(50.26)\end{array}$ & $\begin{array}{c}13.80 \\
14.55 \\
14.05 \\
14.13 \\
(62.85) \\
(2) \\
\end{array}$ & $\begin{array}{c}7.9 \\
8.5 \\
7.9 \\
8.1 \\
(36.03)\end{array}$ & $\begin{array}{c}9.1 \\
10.1 \\
9.1 \\
9.4 \\
(41.81)\end{array}$ \\
\hline 5 & $\begin{array}{c}1 \\
2 \\
3 \\
\text { Average } \\
\text { (c.v.. \%) } \\
\end{array}$ & $\begin{array}{c}20.05 \\
23.50 \\
21.25 \\
21.60 \\
(96.08) \\
(8) \\
\end{array}$ & $\begin{array}{l}11.0 \\
10.2 \\
10.8 \\
10.7 \\
(47.59)\end{array}$ & $\begin{array}{l}12.6 \\
13.3 \\
13.8 \\
13.2 \\
(58.71)\end{array}$ & $\begin{array}{c}20.25 \\
18.90 \\
19.95 \\
19.70 \\
(87.63) \\
(4)\end{array}$ & $\begin{array}{c}10.0 \\
10.5 \\
- \\
10.3 \\
(45.81)\end{array}$ & $\begin{array}{c}11.7 \\
12.2 \\
- \\
12.0 \\
(53.38)\end{array}$ & $\begin{array}{c}17.05 \\
18.70 \\
17.85 \\
17.87 \\
(79.49) \\
(5)\end{array}$ & $\begin{array}{l}10.9 \\
12.1 \\
10.1 \\
11.0 \\
(48.93)\end{array}$ & $\begin{array}{l}13.5 \\
13.5 \\
11.8 \\
12.9 \\
(57.38)\end{array}$ \\
\hline 7 & $\begin{array}{c}1 \\
2 \\
3 \\
\text { Average } \\
\text { (c. } v ., 8)\end{array}$ & $\begin{array}{c}23.85 \\
23.90 \\
23.35 \\
23.70 \\
(105.42) \\
(1)\end{array}$ & $\begin{array}{c}11.2 \\
10.6 \\
9.0 \\
10.3 \\
(45.81)\end{array}$ & $\begin{array}{l}13.5 \\
13.0 \\
11.6 \\
12.7 \\
(56.49)\end{array}$ & $\begin{array}{c}22.55 \\
18.55 \\
22.65 \\
21.25 \\
(94.52) \\
(11)\end{array}$ & $\begin{array}{l}11.2 \\
12.5 \\
12.0 \\
11.9 \\
(52.93)\end{array}$ & $\begin{array}{l}13.1 \\
14.2 \\
13.7 \\
13.7 \\
(60.94)\end{array}$ & $\begin{array}{c}19.80 \\
19.90 \\
20.40 \\
20.03 \\
(89.09) \\
(2)\end{array}$ & $\begin{array}{l}11.1 \\
11.5 \\
13.0 \\
11.9 \\
(52.93)\end{array}$ & $\begin{array}{l}13.3 \\
13.3 \\
14.5 \\
13.7 \\
(60.94)\end{array}$ \\
\hline 14 & $\begin{array}{c}1 \\
2 \\
3 \\
\text { Average } \\
(c . v \ldots, 8) \\
\end{array}$ & $\begin{array}{c}26.15 \\
26.40 \\
25.23 \\
25.93 \\
(115.34) \\
(2)\end{array}$ & $\begin{array}{c}11.8 \\
15.4 \\
8.0 \\
11.7 \\
(52.04)\end{array}$ & $\begin{array}{l}14.5 \\
18.0 \\
10.9 \\
14.5 \\
(64.50)\end{array}$ & $\begin{array}{r}23.00 \\
24.45 \\
25.10 \\
24.18 \\
(107.55) \\
(4)\end{array}$ & $\begin{array}{l}13.4 \\
13.8 \\
14.8 \\
14.0 \\
(62.27)\end{array}$ & $\begin{array}{l}15.4 \\
15.7 \\
16.5 \\
15.9 \\
(70.72)\end{array}$ & $\begin{array}{c}22.60 \\
23.45 \\
22.15 \\
22.73 \\
(101(3) \\
(3)\end{array}$ & $\begin{array}{c}13.2 \\
12.5 \\
- \\
12.9 \\
(57.38)\end{array}$ & $\begin{array}{c}16.4 \\
15.5 \\
- \\
16.0 \\
(71.17)\end{array}$ \\
\hline 21 & $\begin{array}{c}1 \\
2 \\
3 \\
\text { Average } \\
\text { (c.v., } 8 \text { ) } \\
\end{array}$ & $\begin{array}{r}27.10 \\
24.85 \\
25.70 \\
25.88 \\
(115(11) \\
(4)^{2}\end{array}$ & $\begin{array}{c}16.2 \\
12.2 \\
= \\
14.2 \\
(63.16)\end{array}$ & $\begin{array}{c}20.7 \\
14.7 \\
- \\
17.7 \\
(78.73)\end{array}$ & $\begin{array}{c}26.00 \\
25.85 \\
26.10 \\
25.98 \\
(115.56) \\
(1)\end{array}$ & $\begin{array}{l}14.8 \\
14.9 \\
14.7 \\
14.8 \\
(65.83)\end{array}$ & $\begin{array}{l}17.0 \\
17.2 \\
16.8 \\
17.0 \\
(75.62)\end{array}$ & $\begin{array}{c}25.65 \\
25.55 \\
25.80 \\
25.67 \\
(114.18) \\
(1)\end{array}$ & $\begin{array}{l}17.6 \\
15.2 \\
16.1 \\
16.3 \\
(72.50)\end{array}$ & $\begin{array}{l}20.2 \\
18.0 \\
18.5 \\
18.9 \\
(84.07)\end{array}$ \\
\hline 28 & $\begin{array}{c}1 \\
2 \\
3 \\
\text { Average } \\
\text { (c. } ., 8 \text { ) }\end{array}$ & $\begin{array}{r}28.05 \\
26.35 \\
27.25 \\
27.22 \\
(121.07) \\
(3)\end{array}$ & $\begin{array}{l}14.8 \\
15.0 \\
11.3 \\
13.7 \\
(60.94)\end{array}$ & $\begin{array}{l}17.7 \\
17.8 \\
15.1 \\
16.9 \\
(75.17)\end{array}$ & $\begin{array}{c}27.15 \\
24.60 \\
27.20 \\
(117.32 \\
(6) \\
\end{array}$ & $\begin{array}{l}16.8 \\
13.6 \\
14.7 \\
15.0 \\
(66.72)\end{array}$ & $\begin{array}{c}18.7 \\
16.0 \\
17.5 \\
17.4 \\
(77.40)\end{array}$ & $\begin{array}{c}26.50 \\
26.80 \\
25.10 \\
26.13 \\
(116.23) \\
(3)\end{array}$ & $\begin{array}{l}15.8 \\
17.0 \\
14.8 \\
15.9 \\
(70.72)\end{array}$ & $\begin{array}{l}17.9 \\
19.5 \\
17.5 \\
18.3 \\
(81.40)\end{array}$ \\
\hline 42 & $\begin{array}{c}1 \\
2 \\
3 \\
\text { Average } \\
\text { (C.v., } 8 \text { ) }\end{array}$ & $\begin{array}{l}- \\
- \\
- \\
- \\
-\end{array}$ & $\begin{array}{l}- \\
- \\
- \\
-\end{array}$ & $\begin{array}{l}- \\
- \\
- \\
-\end{array}$ & $\begin{array}{c}26.15 \\
27.25 \\
26.00 \\
26.46 \\
(117.69) \\
(3)\end{array}$ & $\begin{array}{l}17.6 \\
17.2 \\
17.3 \\
17.4 \\
(77.40)\end{array}$ & $\begin{array}{l}19.8 \\
19.3 \\
19.2 \\
19.4 \\
(81.84)\end{array}$ & $\begin{array}{c}28.60 \\
26.10 \\
29.10 \\
27.93 \\
(124.23) \\
(7)\end{array}$ & $\begin{array}{l}19.7 \\
18.8 \\
19.0 \\
19.2 \\
(85.40)\end{array}$ & $\begin{array}{l}23.0 \\
21.7 \\
21.9 \\
22.2 \\
(98.75)\end{array}$ \\
\hline
\end{tabular}

$9 / p$ is the maximum pull-out load. Slip is the movement of the unloaded end of the No. 6 bar relative to the surface of the concrete. Kip $=1000 \mathrm{lbf} .=4448 \mathrm{~N}$. Slip of $.001 \mathrm{in}=.0254 \mathrm{~mm}$. c.v. = Coefficient of variation. 

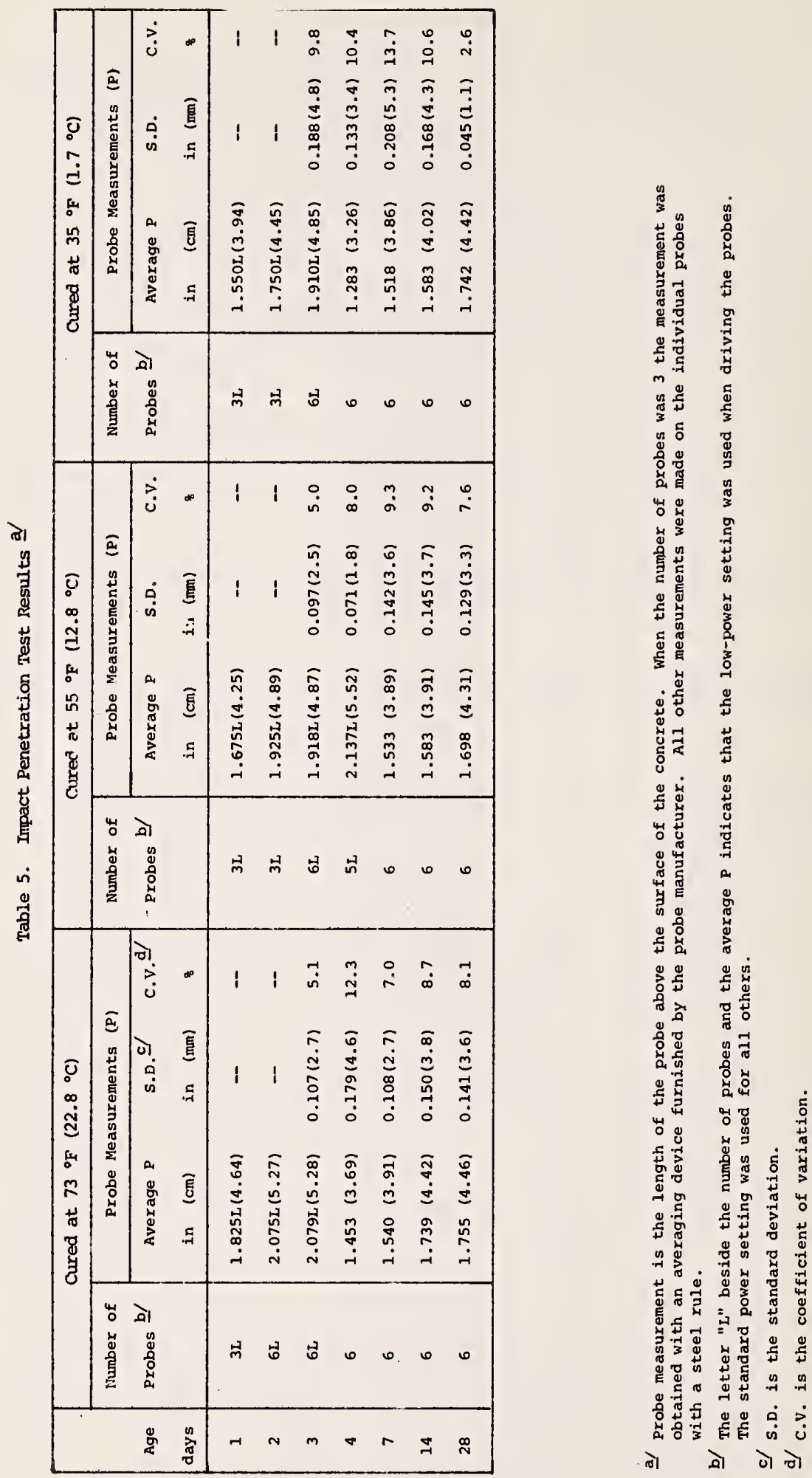


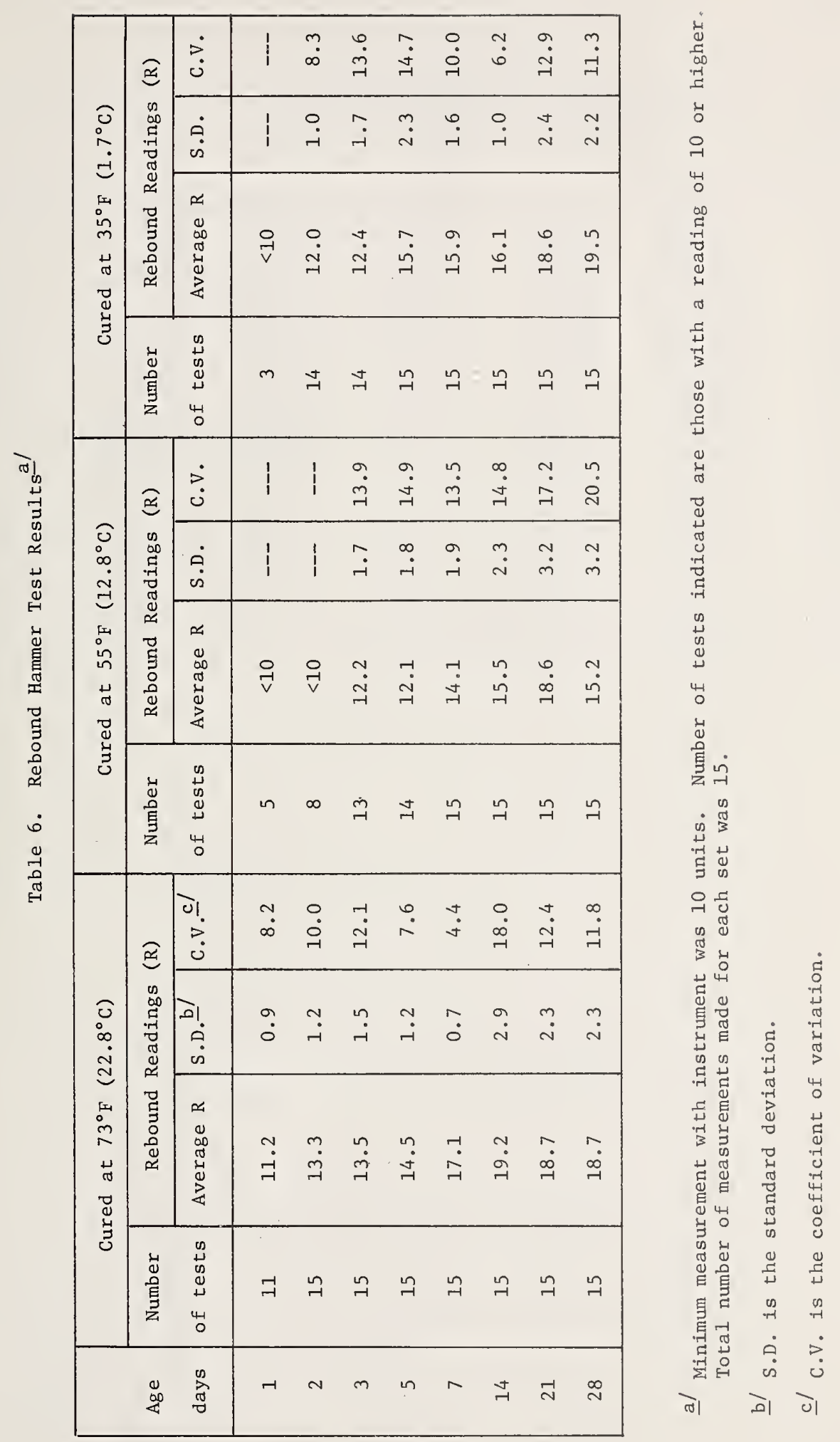


Table 7. Mean Temperature of Concrete During Each Age Interval

\begin{tabular}{|c|cc|cc|cc|}
\hline \multirow{2}{*}{$\begin{array}{c}\text { Age } \\
\text { Interval }\end{array}$} & \multicolumn{6}{|c|}{ Mean Temperature During Interval } \\
\cline { 2 - 7 } days & $73^{\circ} \mathrm{F}$ & $\left(22.8^{\circ} \mathrm{C}\right)$ & $55{ }^{\circ} \mathrm{F}$ & $\left(12.8{ }^{\circ} \mathrm{C}\right)$ & $35{ }^{\circ} \mathrm{F}$ & $\left(1.7{ }^{\circ} \mathrm{C}\right)$ \\
\hline $0-1$ & ${ }^{\circ} \mathrm{F}$ & $\left({ }^{\circ} \mathrm{C}\right)$ & ${ }^{\circ} \mathrm{F}$ & $\left({ }^{\circ} \mathrm{C}\right)$ & ${ }^{\circ} \mathrm{F}$ & $\left({ }^{\circ} \mathrm{C}\right)$ \\
$1-2$ & 79.9 & $(26.6)$ & 58.8 & $(14.9)$ & 55.9 & $(13.3)$ \\
$2-3$ & 72.8 & $(22.7)$ & 58.4 & $(14.7)$ & 38.6 & $(3.7)$ \\
$3-5$ & 73.0 & $(22.8)$ & 58.3 & $(14.6)$ & 38.1 & $(3.4)$ \\
$5-7$ & 73.0 & $(22.8)$ & 57.5 & $(14.2)$ & 36.7 & $(2.6)$ \\
$7-14$ & 72.5 & $(22.5)$ & 57.2 & $(14.0)$ & 35.9 & $(1.9)$ \\
$14-21$ & 72.3 & $(22.4)$ & 56.5 & $(13.6)$ & 38.4 & $(3.6)$ \\
$21-28$ & 73.4 & $(23.0)$ & 56.4 & $(13.6)$ & 41.9 & $(5.9)$ \\
$28-42$ & 72.8 & $(22.7)$ & 56.4 & $(13.6)$ & 42.0 & $(5.6)$ \\
\hline
\end{tabular}


Table 8. Maturity Value of Concrete

\begin{tabular}{|c|rc|r|r|rr|}
\hline \multirow{2}{*}{$\begin{array}{c}\text { Age } \\
\text { Interval } \\
\text { (days) }\end{array}$} & $73^{\circ} \mathrm{F}$ & $\left(22.8^{\circ} \mathrm{C}\right)$ & $55^{\circ} \mathrm{F}$ & $\left(12.8^{\circ} \mathrm{C}\right)$ & $35^{\circ} \mathrm{F}$ & $\left(1.7{ }^{\circ} \mathrm{C}\right)$ \\
\cline { 2 - 7 } $0-1$ & 69.9 & $(38.8)$ & 48.8 & $(27.1)$ & 45.9 & $(25.5)$ \\
$0-2$ & 132.7 & $(73.7)$ & 97.2 & $(54.0)$ & 74.5 & $(41.4)$ \\
$0-3$ & 195.7 & $(108.7)$ & 145.5 & $(80.8)$ & 102.6 & $(57.0)$ \\
$0-5$ & 321.7 & $(178.7)$ & 240.5 & $(133.6)$ & 156.1 & $(86.7)$ \\
$0-7$ & 446.7 & $(248.2)$ & 334.8 & $(186.0)$ & 207.9 & $(115.5)$ \\
$0-14$ & 882.9 & $(490.5)$ & 660.3 & $(366.8)$ & 407.0 & $(226.1)$ \\
$0-21$ & 1326.4 & $(736.9)$ & 985.1 & $(547.3)$ & 630.1 & $(350.1)$ \\
$0-28$ & 1764.8 & $(980.4)$ & 1309.6 & $(727.6)$ & 854.3 & $(474.6)$ \\
$0-42$ & & & 1941.6 & $(1078.7)$ & 1212.1 & $(673.4)$ \\
& & & & & & \\
\hline
\end{tabular}


Table 9. Statistical Properties Associated with the Regression Equations

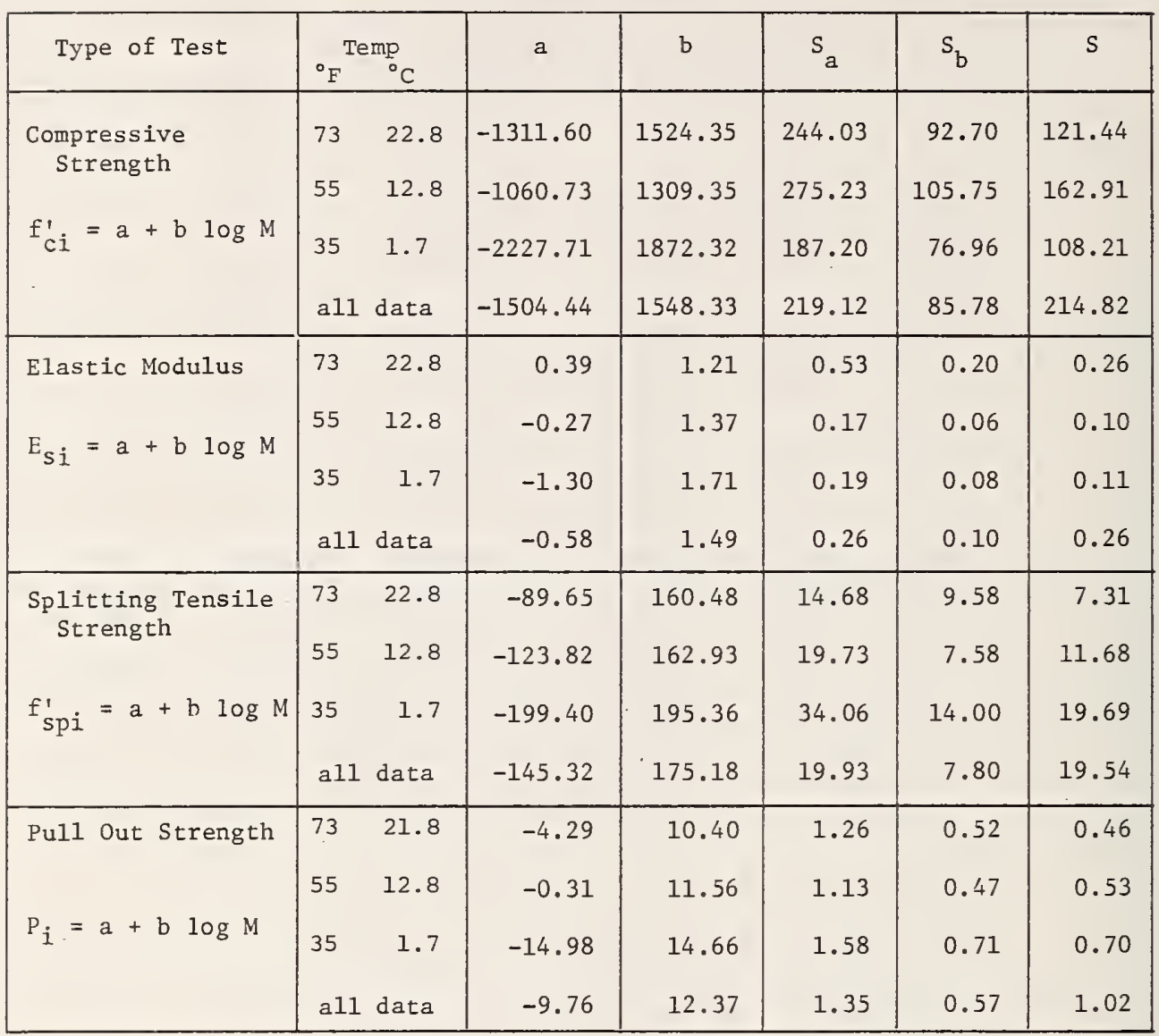

$\mathrm{S}_{\mathrm{a}}$ : Standard error of the regression coefficient a

$S_{b}:$ Standard error of the regression coefficient $b$

S : Sample standard deviation from regression line (Residual standard deviation) 


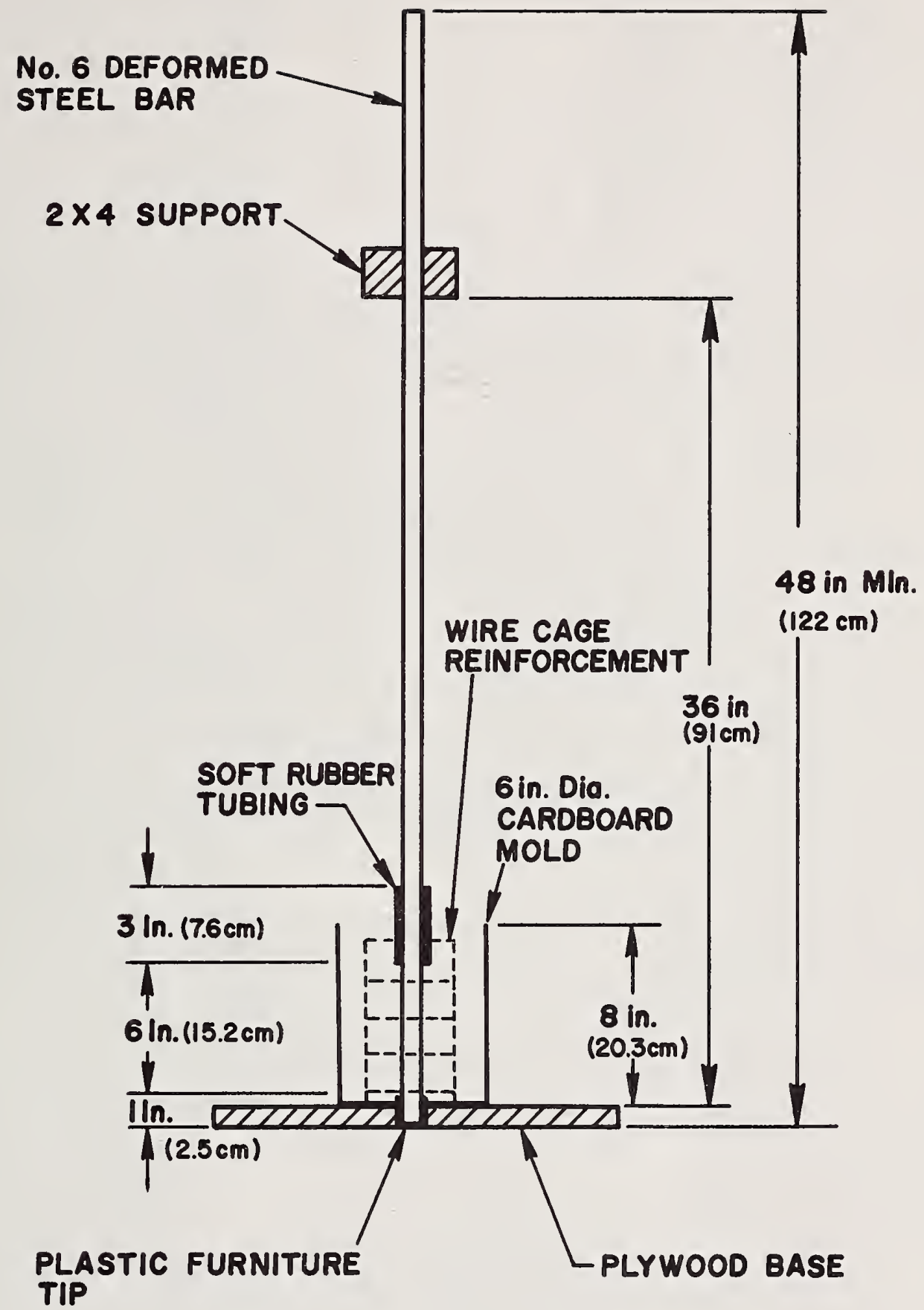

FIGURE 1 Section Through Pull-out

Specimen Rack and Mold 


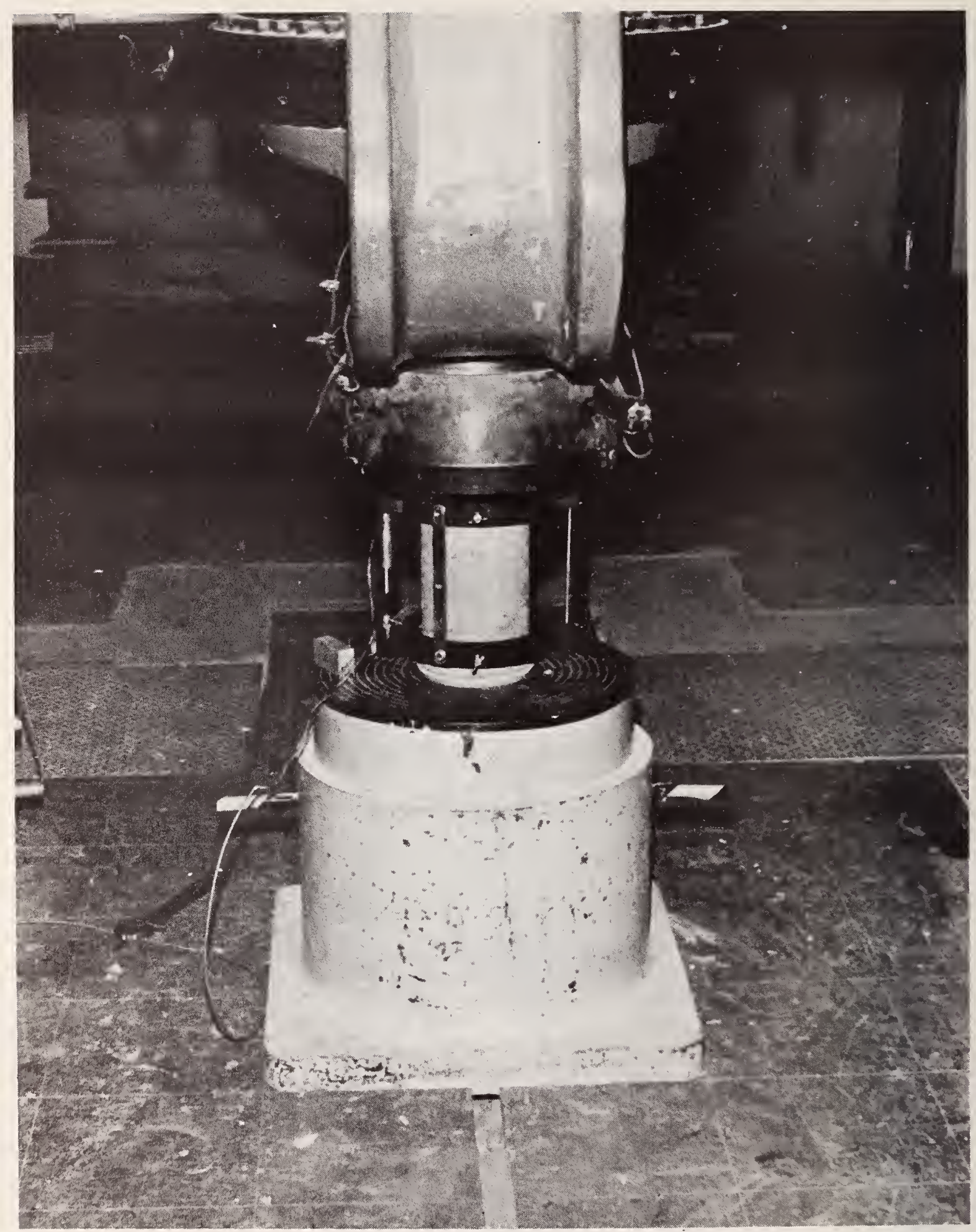

FIGURE 2 Compressive Test of Cylinder 


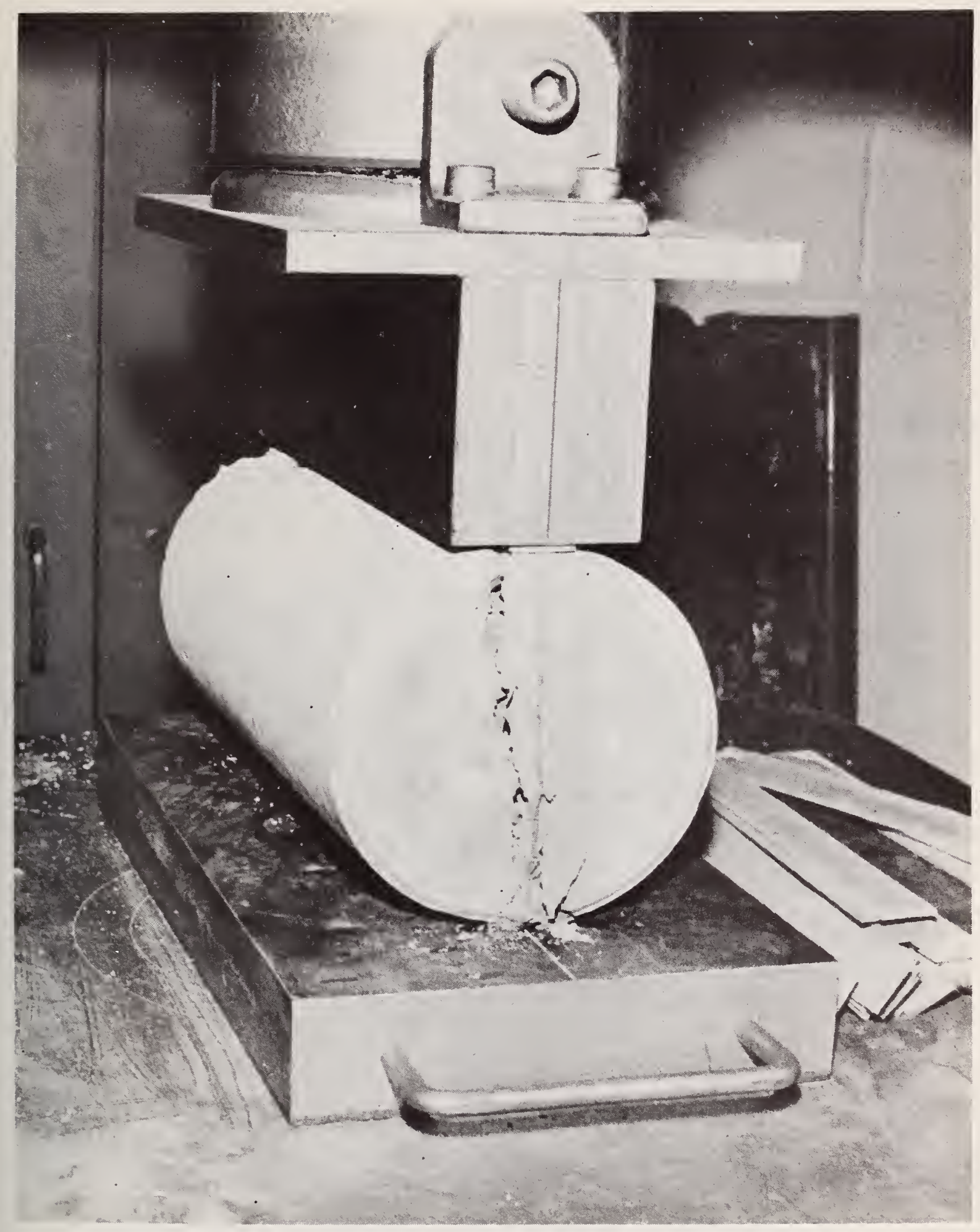

FIGURE 3 Splitting Tensile Test of Cylinder 


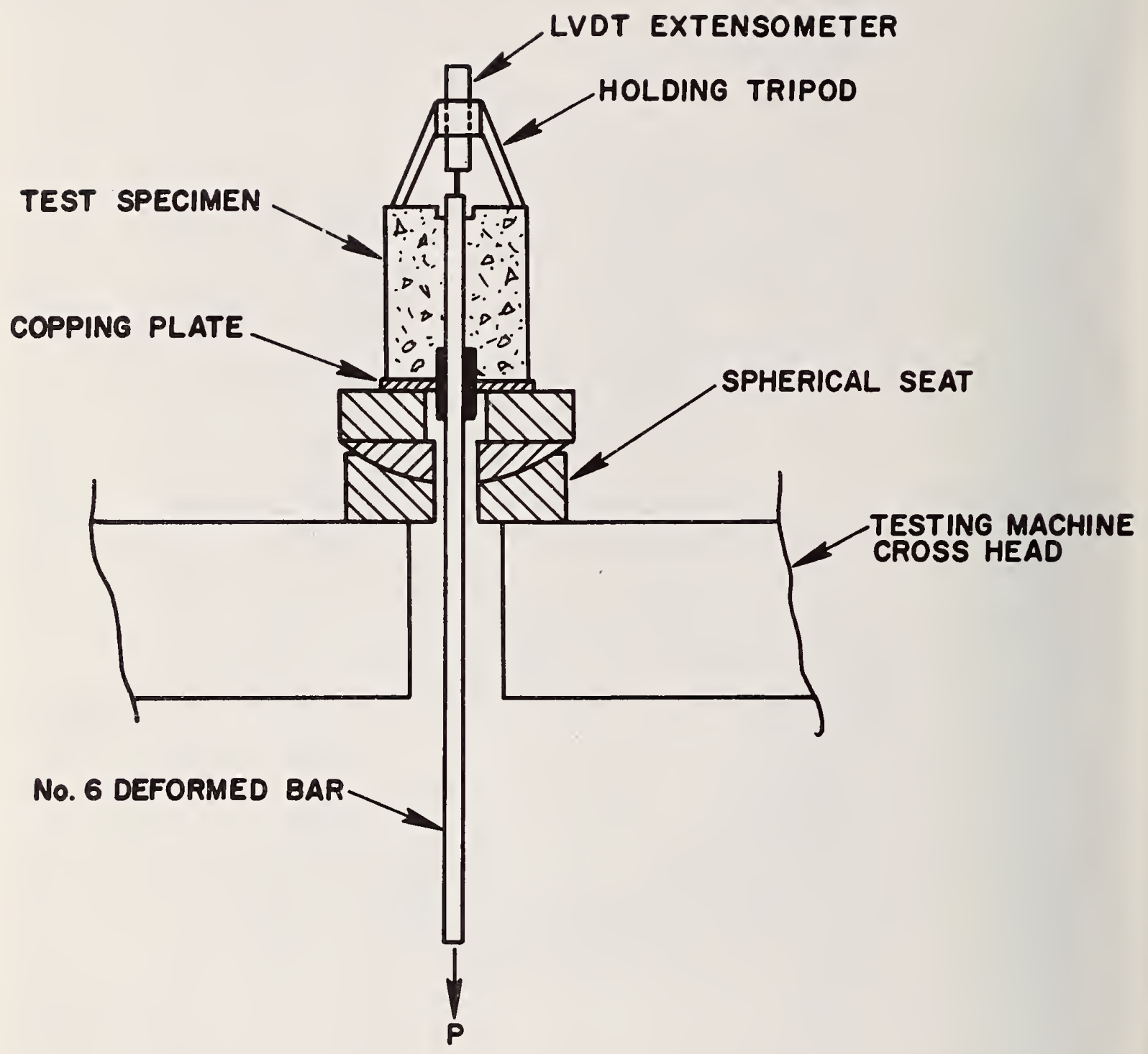

FIGURE 4 Pull-out Test Setup 


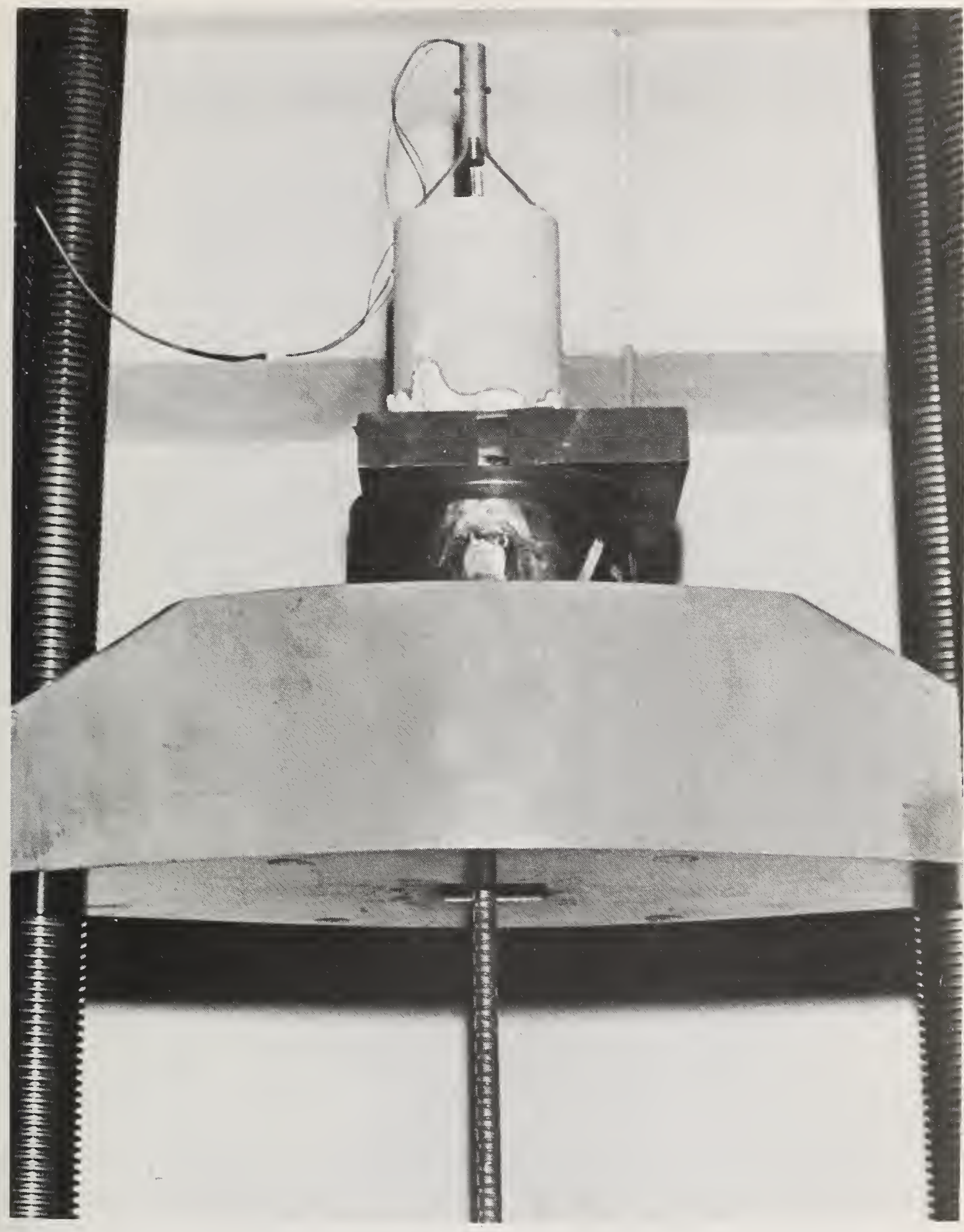

FIGURE 5 Pull-out Bond Test 


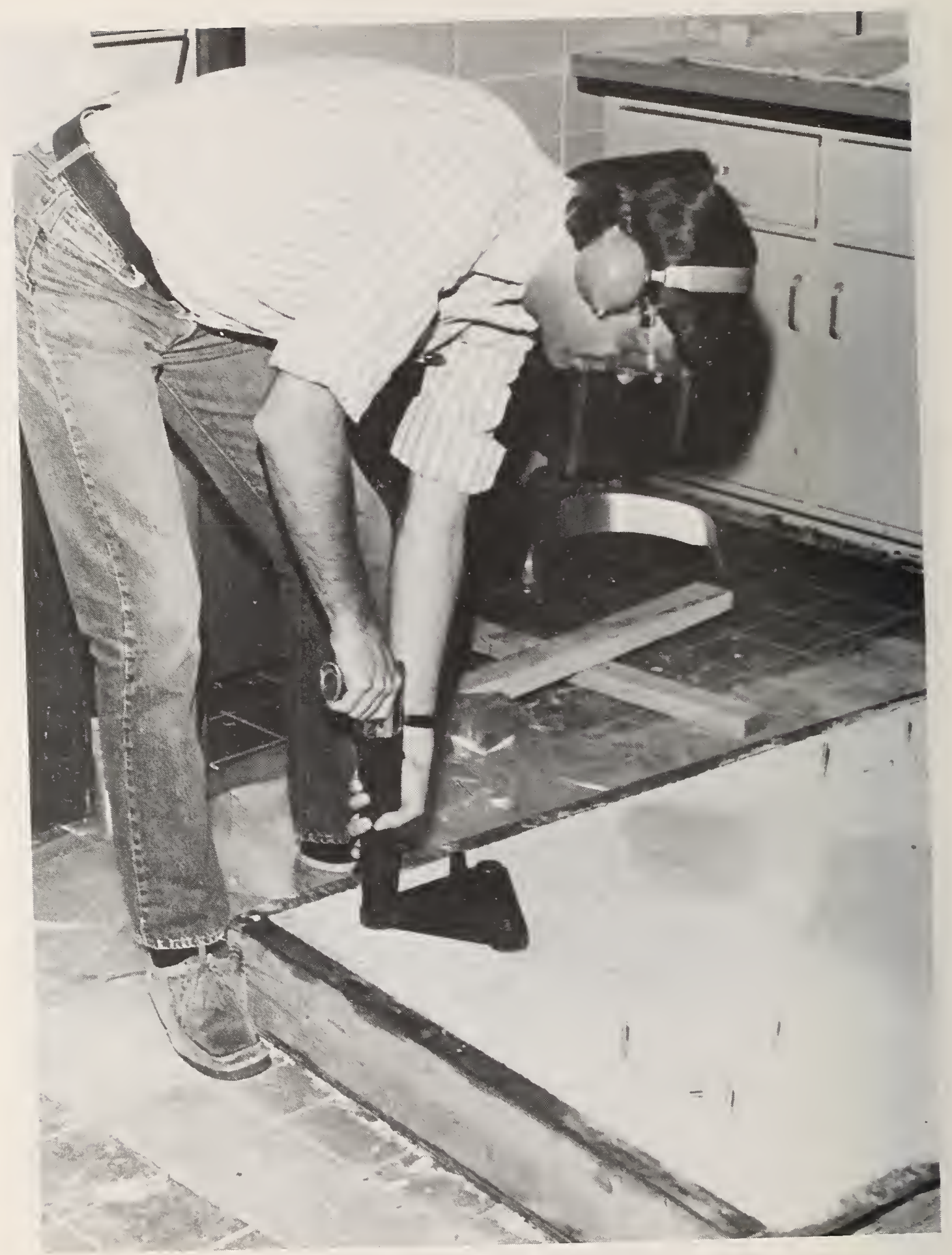

FIGURE 6 Probe Penetration Test 


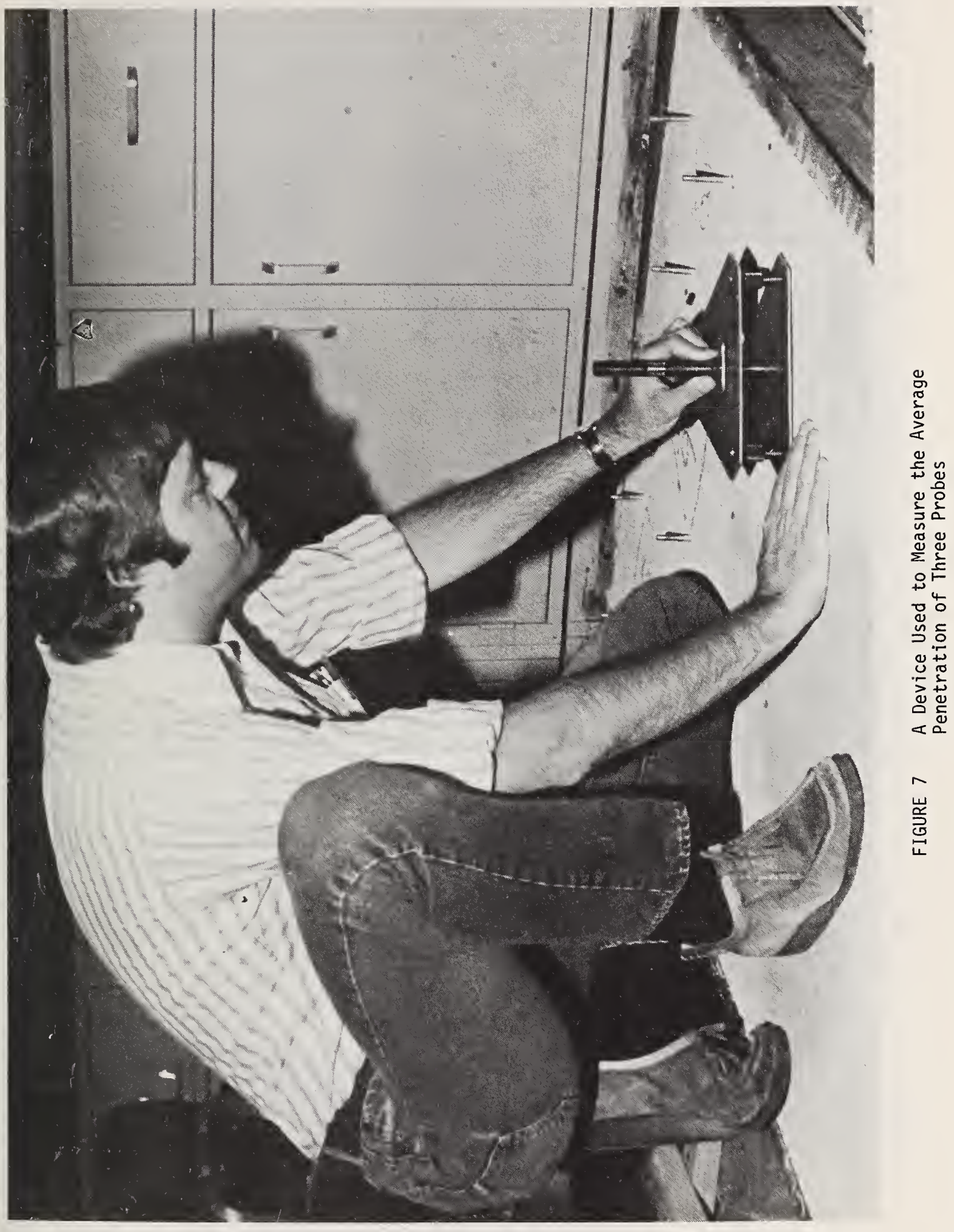




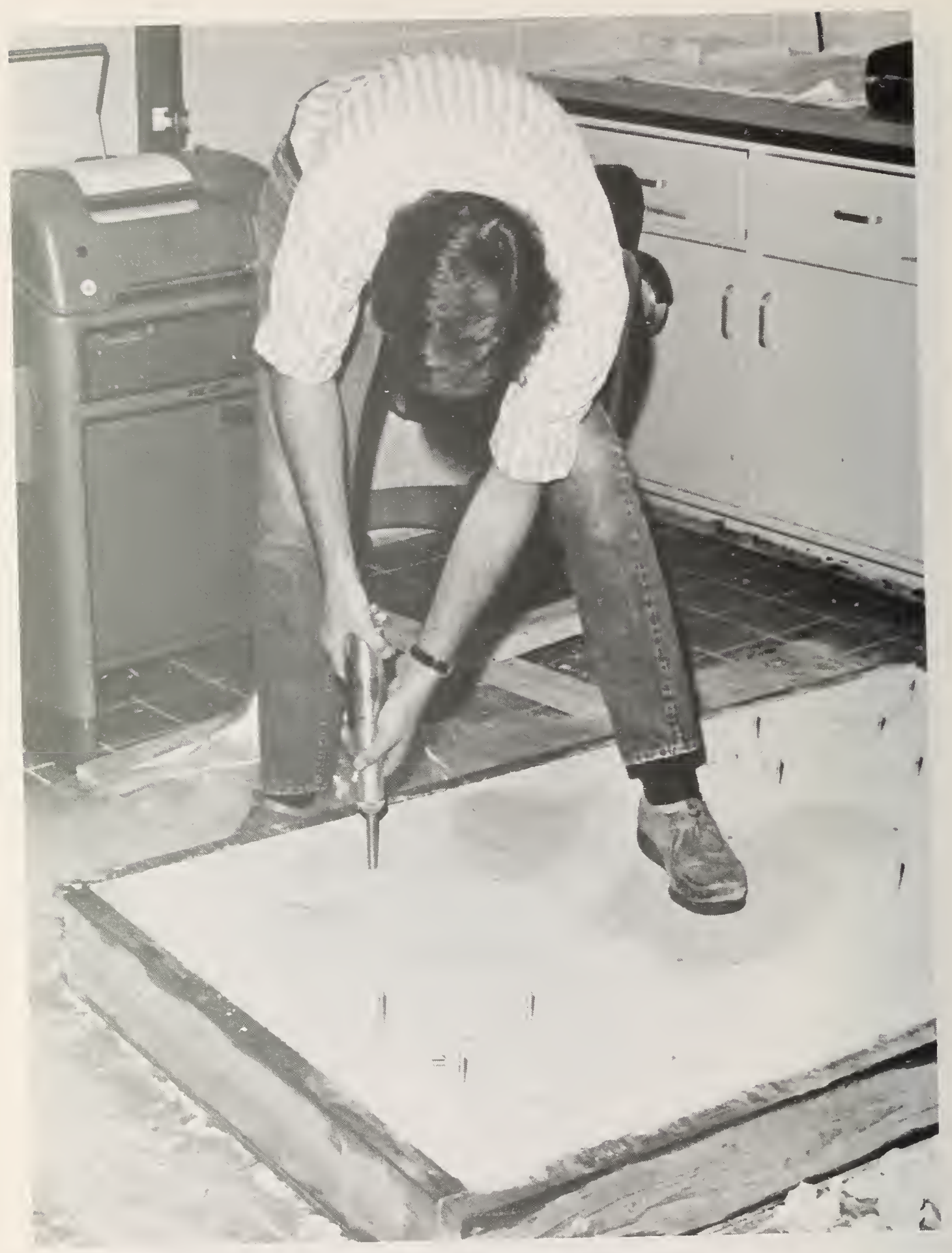

FIGURE 8 Rebound Hammer Test 


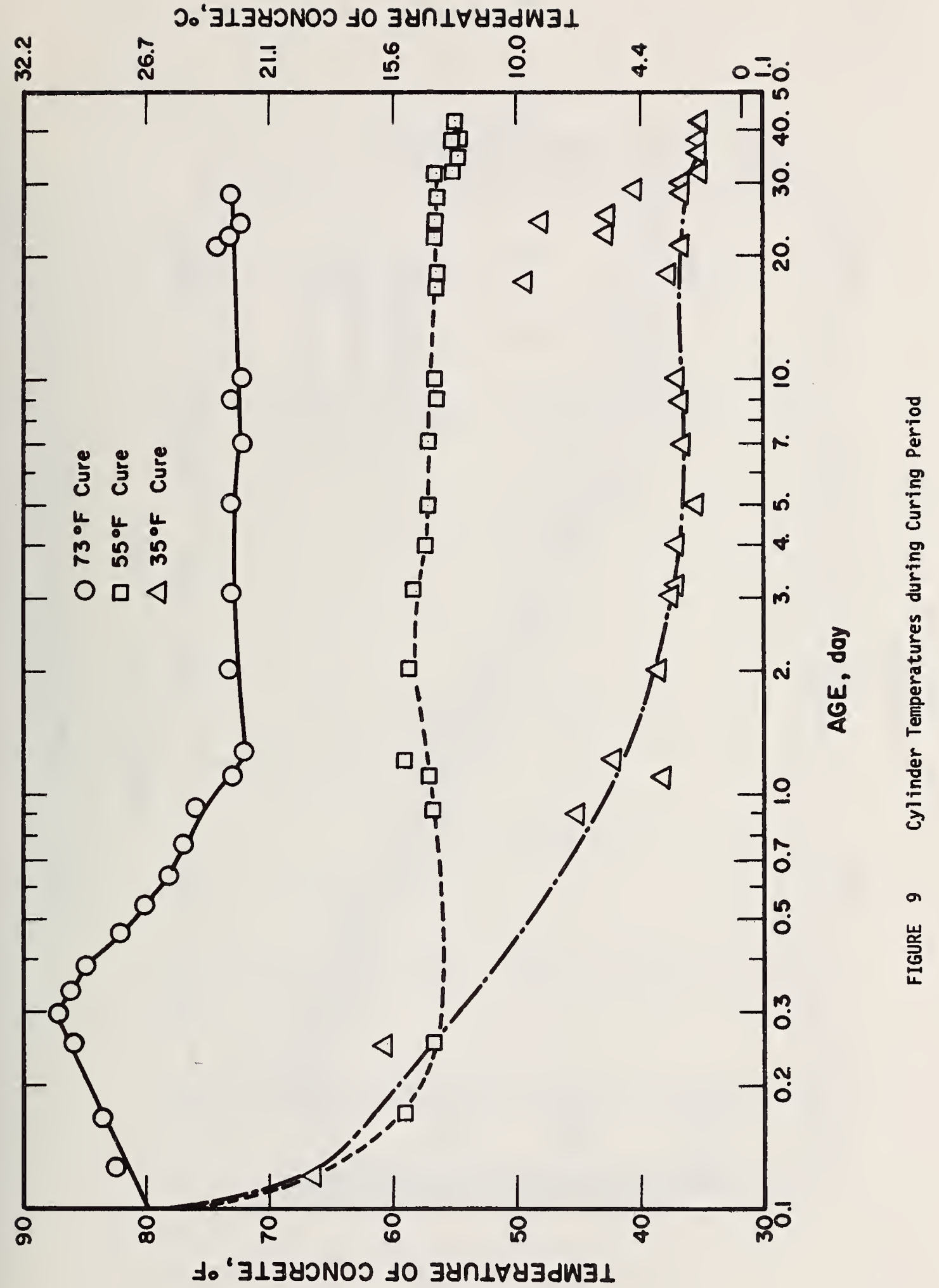




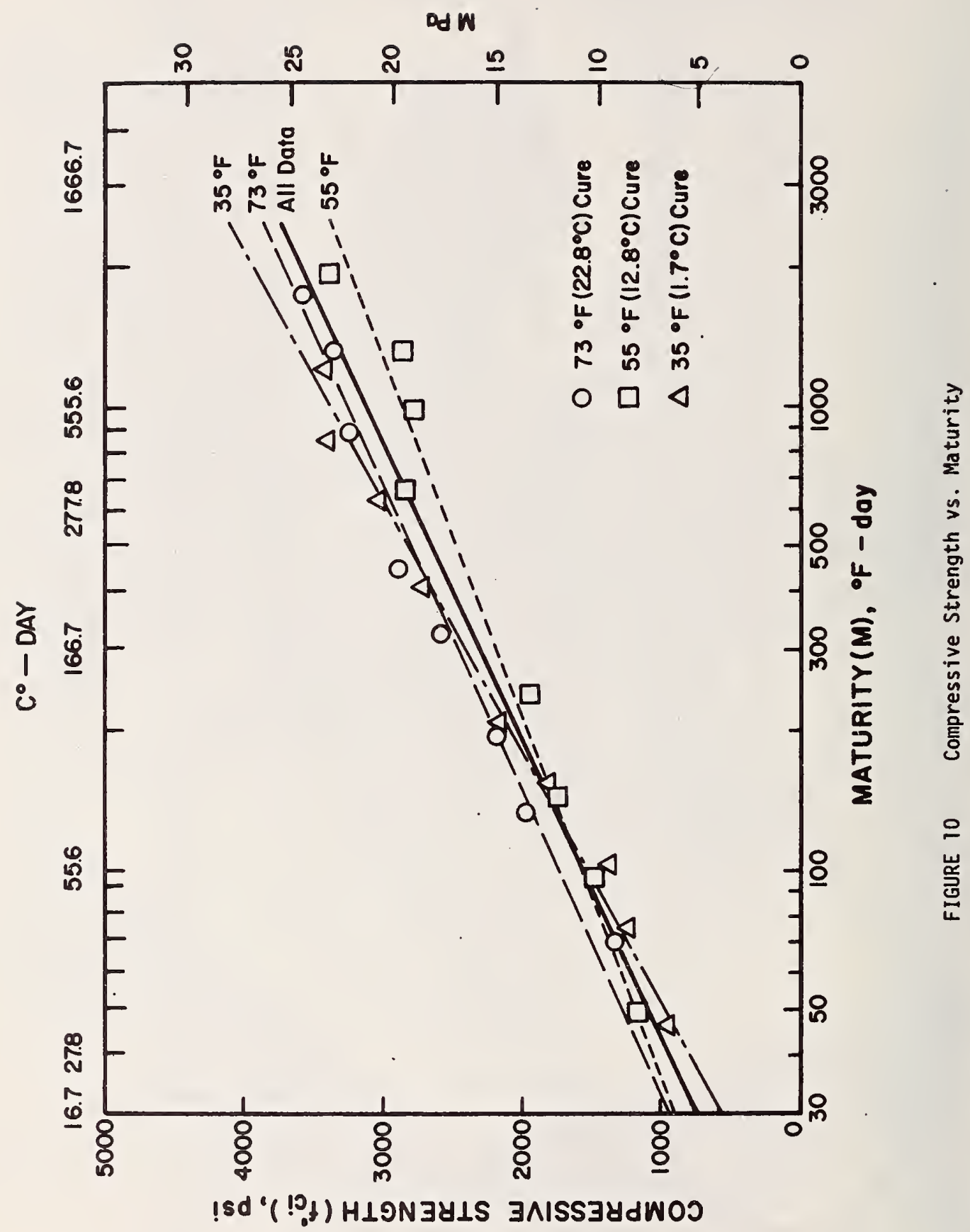




\section{$73^{\circ} \mathrm{F} \ldots\left(22.8^{\circ} \mathrm{C}\right)$}

\section{$55^{\circ} \mathrm{F}$}

\section{$35^{\circ} \mathrm{F} \ldots\left(1.7^{\circ} \mathrm{C}\right)$}

All Data

\begin{tabular}{|c|c|c|c|c|}
\hline$L$ & 1 & $\perp$ & $\perp$ & $\perp$ \\
\hline 3000 & -2500 & -2000 & -1500 & -1000 \\
\hline
\end{tabular}

(a)

$$
a \pm t s_{a}
$$

$73^{\circ} \mathrm{F}$

$55^{\circ} \mathrm{F}$

$35^{\circ} \mathrm{F} \cdots\left(1.7^{\circ} \mathrm{C}\right)$

\begin{tabular}{|c|c|c|c|c|c|}
\hline & All Data & \%.... & & & \\
\hline L & $\perp$ & 1 & $\perp$ & $\perp$ & $\longrightarrow$ \\
\hline 500 & 1000 & 1500 & 2000 & 2500 & 3000 \\
\hline
\end{tabular}

FIGURE 11 The Lower and Upper Limits of Intercepts and Slopes of Regression Lines of Compressive Strength vs. Maturity 


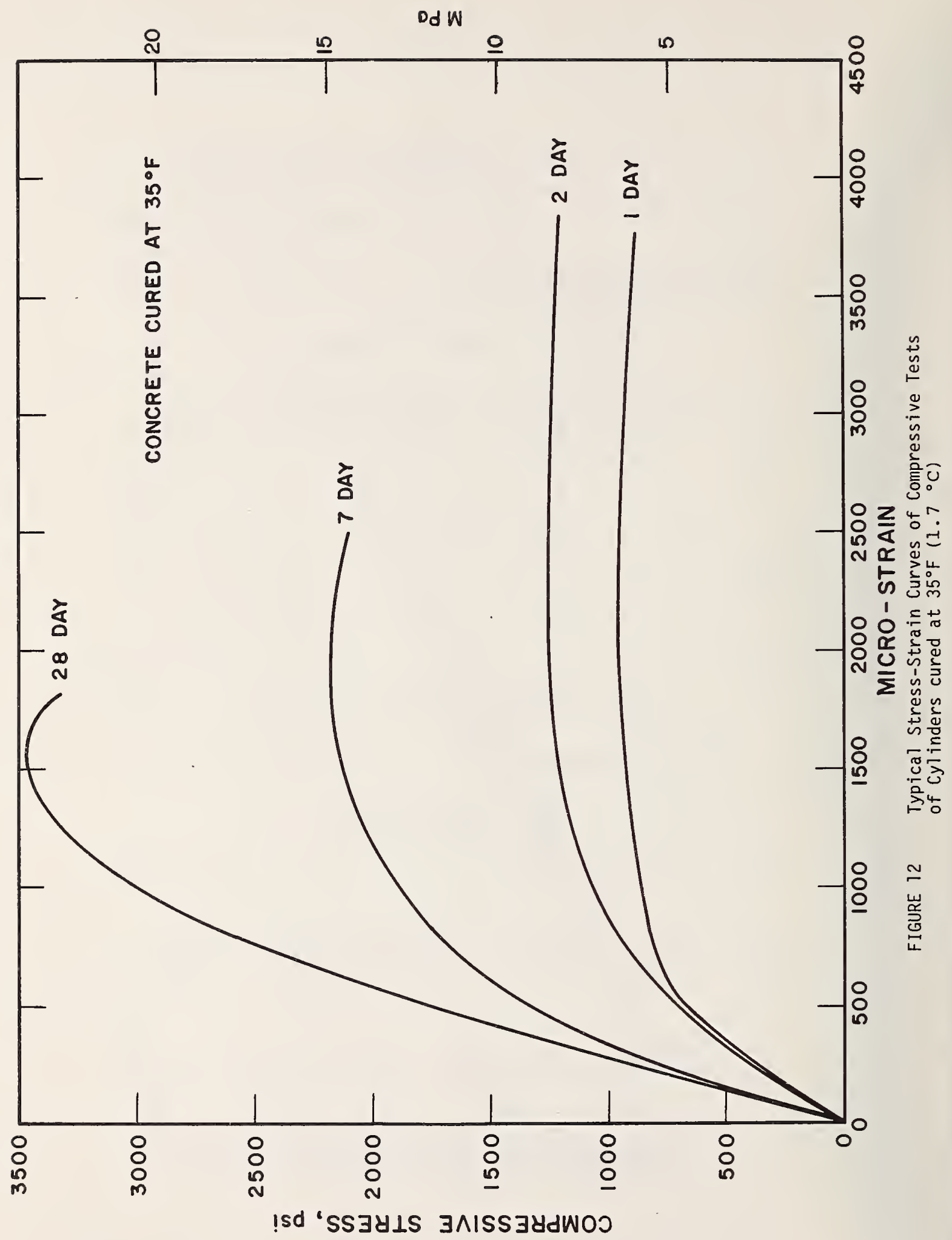




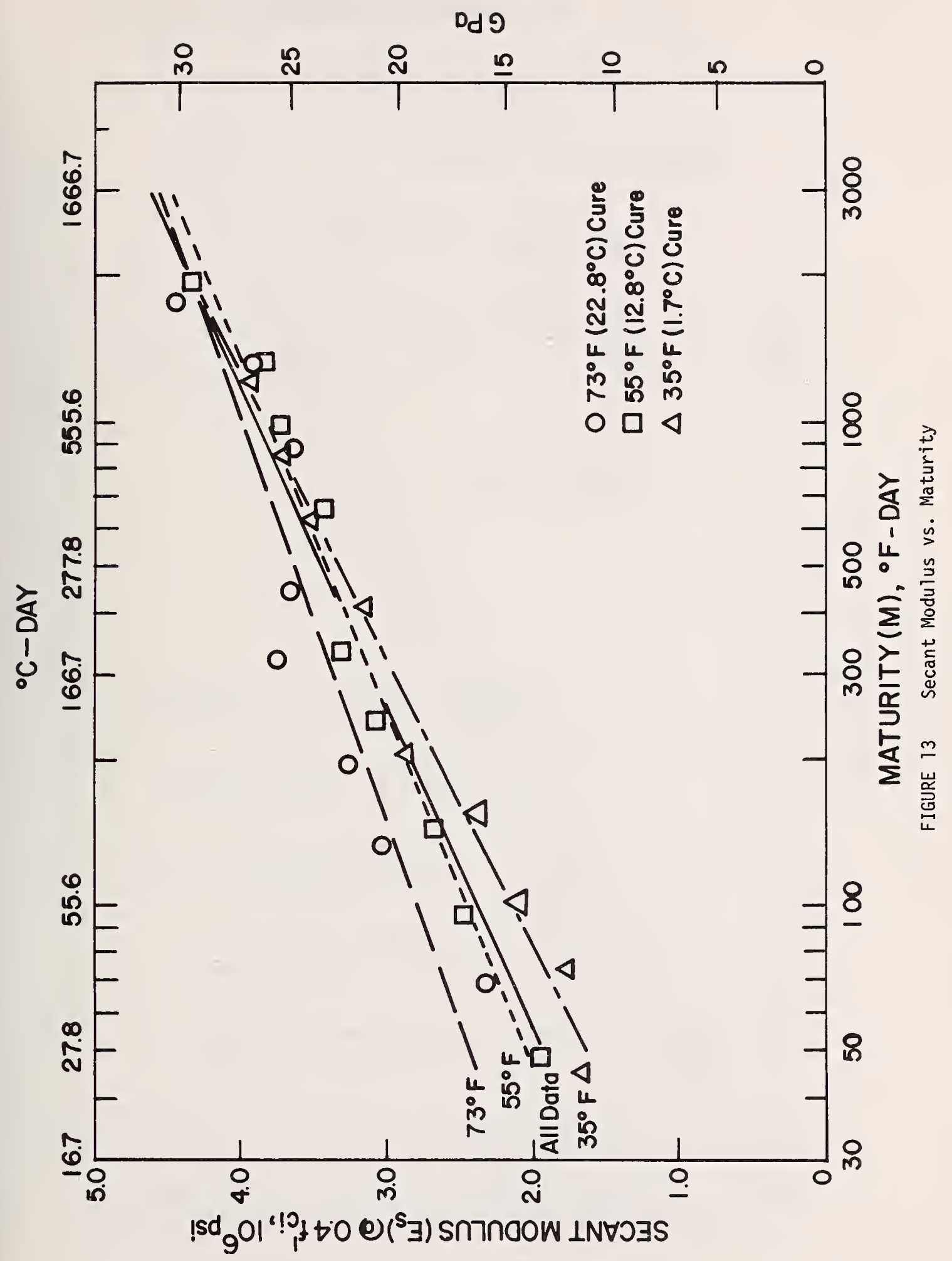


$73^{\circ} \mathrm{F}$

$55^{\circ} \mathrm{F} \approx\left(12.8^{\circ} \mathrm{C}\right)$

$35^{\circ} \mathrm{F}\left(1.7^{\circ} \mathrm{C}\right)$

ALL DATA

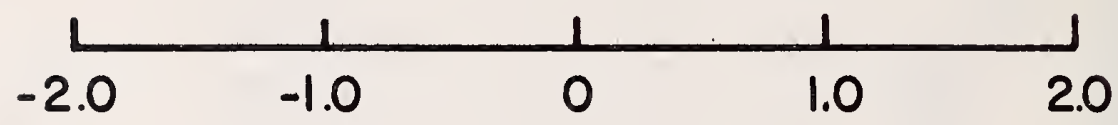

(a) $0 \pm \uparrow S o$

$73^{\circ} \mathrm{F}$

$55^{\circ} \mathrm{F} \quad\left(12.8^{\circ} \mathrm{C}\right)$

$35^{\circ} \mathrm{F} \ldots\left(1.7^{\circ} \mathrm{C}\right)$

ALL DATA

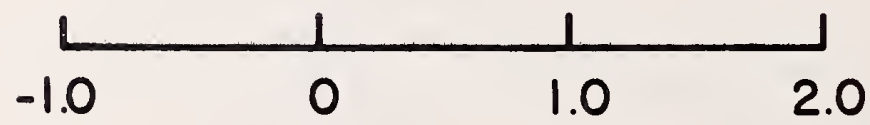

(b) $b \pm+S_{b}$

FIGURE 14 The Lower and Upper Limits of Intercepts and Slopes of Regression Lines of Secant Modulus vs. Maturity 


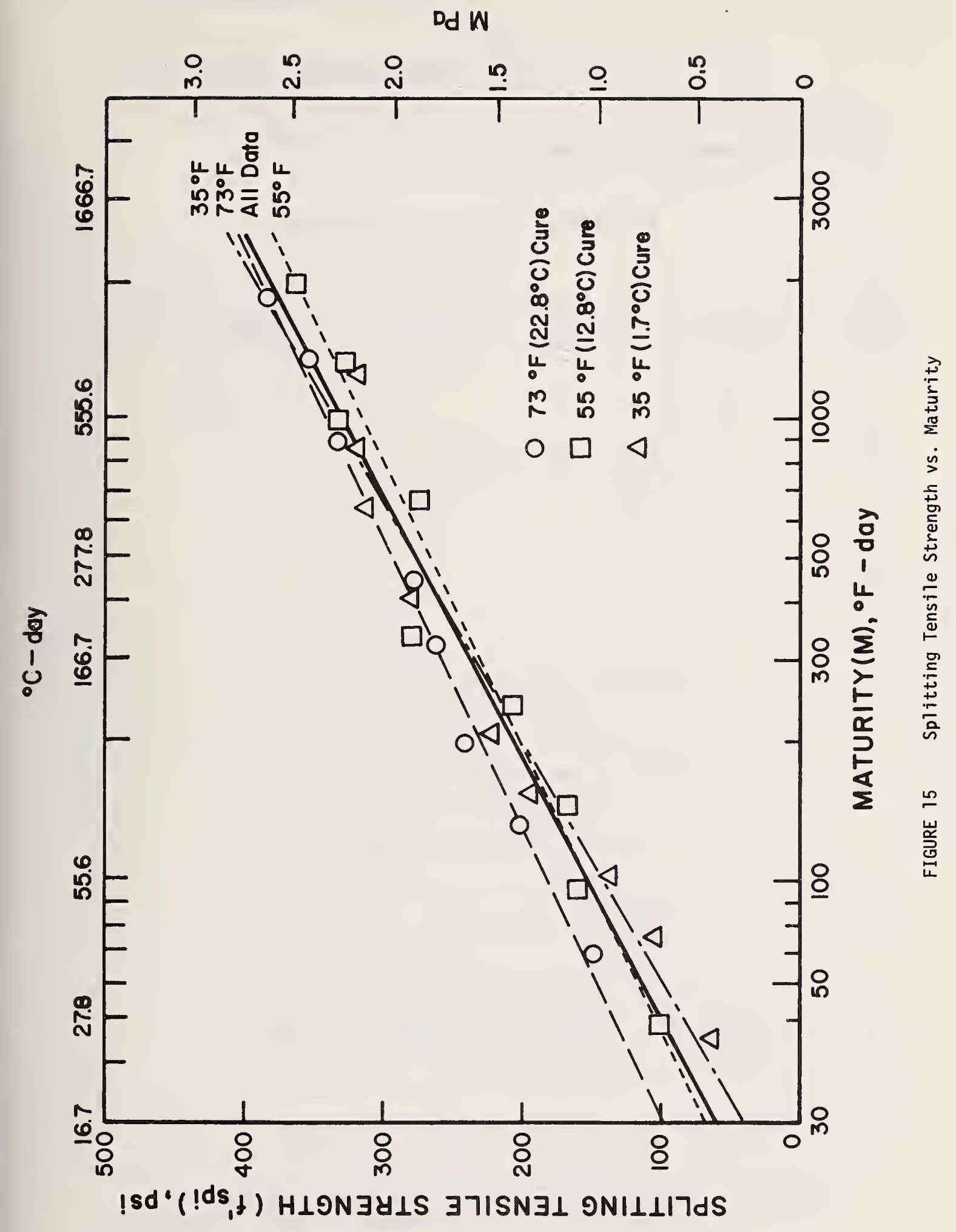




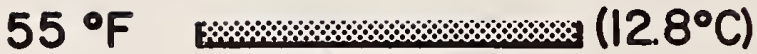

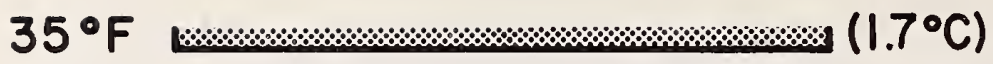

All Data

\begin{tabular}{llllll}
\hline & 1 & 1 & 1 & 1 & \\
-300 & -250 & -200 & -150 & -100 & -50
\end{tabular}

(a) $a \pm t S_{a}$

$73^{\circ} \mathrm{F}$

$55^{\circ} \mathrm{F}$

$35^{\circ} \mathrm{F}$

All Data «

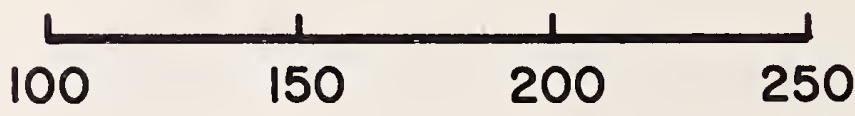

(b) $b \pm t S_{b}$

FIGURE 16 The Lower and Upper Limits of Intercepts and STopes of Regression Lines of Splitting Tensile Strength vs. Maturity 


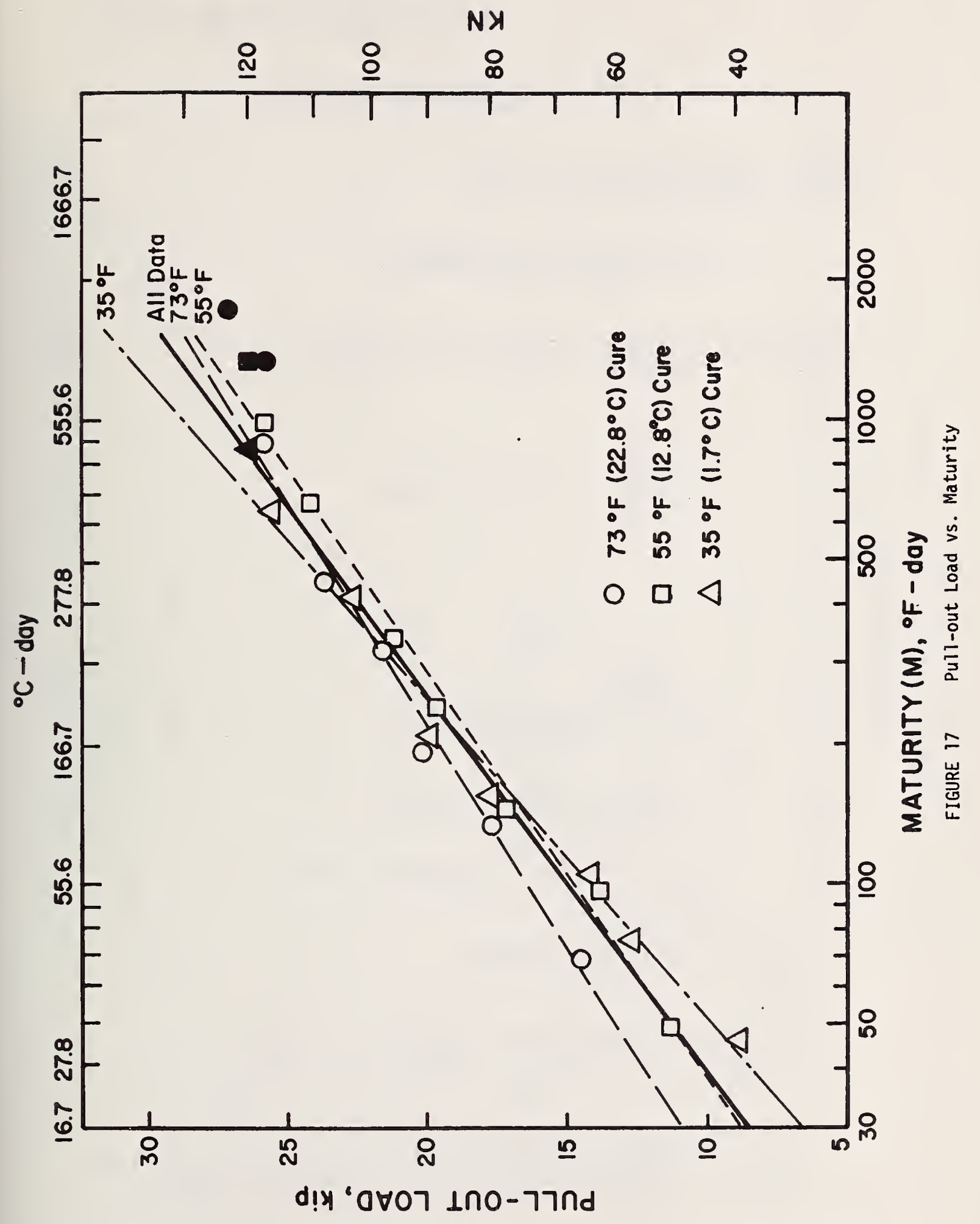




\section{$73^{\circ} \mathrm{F}$}

$55^{\circ} \mathrm{F}$

$35^{\circ} \mathrm{F}$

All Data

$\begin{array}{lcccc}1 & 1 & 1 & 1 \\ -20 & -15 & -10 & -5 & 0\end{array}$

(a) $a \pm t S a$

$73^{\circ} \mathrm{F}$

$55^{\circ} \mathrm{F} \approx\left(12.8^{\circ} \mathrm{C}\right)$

$35^{\circ} \mathrm{F} \ldots\left(1.7^{\circ} \mathrm{C}\right)$

\section{All Dafa}

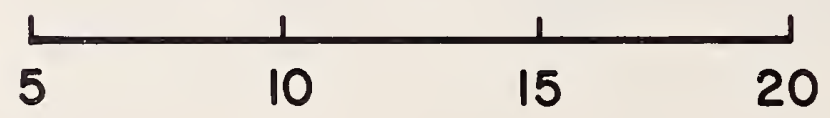

(b) $\quad b \pm t s_{b}$

FIGURE 18 The Lower and Upper Limits of Intercepts and Slopes of Regression Lines of Pull-out Loads vs. Maturity 


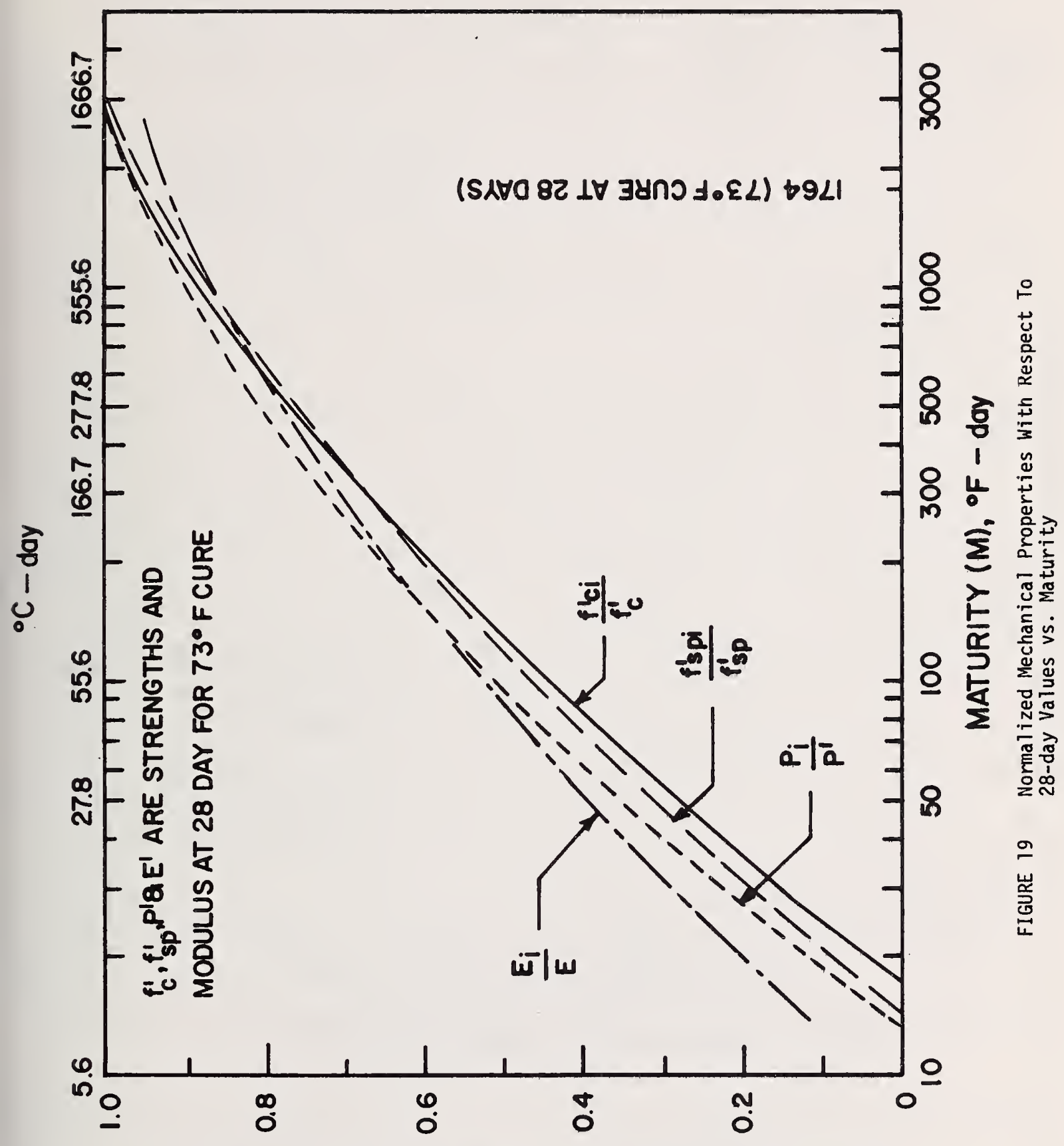

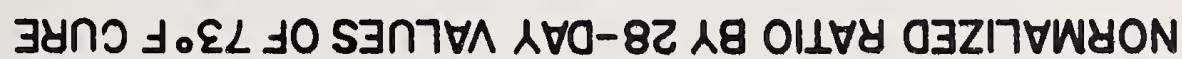




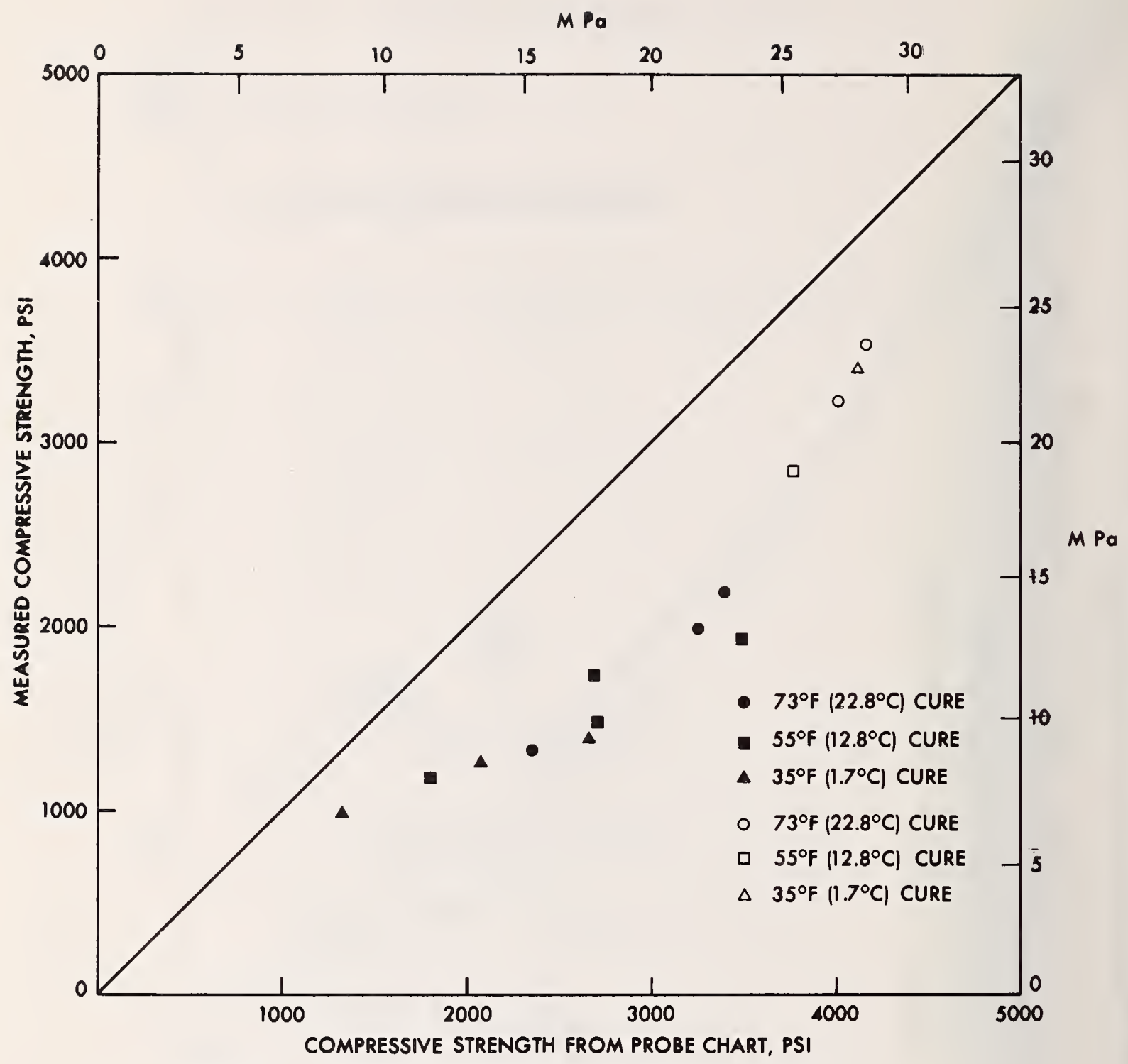

FIGURE 20 Comparision of Measured Compressive Strength vs. Compressive Strength from Probe Chart 
KBS-I14A (REV. 7-73)

U.S. DEPT. OF COMM.

BIBLIOGRAPHIC DATA

SHEET

4. TITLE AND SUBTITLE
1. PUIBLICATION OR REPORT NO.

Technical Note 932 2. Gov't Accession
No.

3. Recipient's Accession No.

5. Publication Date

CONCRETE STRENGTH DURING CONSTRUCTION

December 1976

6. Performing Organization Code

8. Performing Organ. Report No.

10. Project/Task/Work Unit No.

11. Contract/Grant No.

NATIONAL BUREAU OF STANDARDS

DEPARTMENT OF COMMERCE

WASHINGTON, D.C. 20234

12. Sponsoring Organization Name and Complete Address (Street, City, State, 3.IP)

Same as No. 9

13. Type of Report \& Period

Covered

Interim

14. Sponsoring Agency Code

1S. SUPPLEMENTARY NOTES

The content of this report will be published as an AC1 Symposium paper in mid-1977 under the title of "Mechanical Properties of Concrete at Early Ages."

16. ABSTRACT (A 200-word or less tactual summary of most significant information. If document includes a significant bibliography or literature survey, mention it here.)

The early strength gain characteristics of a concrete at various temperatures was investigated in this study. In addition, the applicability of two widely known nondestructive evaluation methods were examined for the purpose of determining the compressive strength of concrete at early ages.

For destructive evaluation, standard cylinder compression tests, splitting tensile tests and pul1-out tests were made on specimens cured at $73^{\circ} \mathrm{F}\left(22.8{ }^{\circ} \mathrm{C}\right), 55^{\circ} \mathrm{F}(12.8$ $\left.{ }^{\circ} \mathrm{C}\right)$ and $35^{\circ} \mathrm{F}\left(1.7^{\circ} \mathrm{C}\right)$. For non-destructive evaluation, both probe penetration and rebound hammer tests were performed on slabs. Tests were carried out at the age of 1 , $2,3,5,7,14,28$ and 42 days after casting the concrete.

Statistical analyses were made to examine the possibility of using maturity of concrete as a parameter to correlate test results of concrete cured at different temperatures. Rate of gain of the splitting tensile strength, pull-out bond strength and elastic modulus were compared with that of compressive strength.

The results show that when related to maturity, the rate of increase in the splittirg tensile strength is about the same as that of the compressive strength, whereas the rate of increase in the pull-out strength and the modulus are slightly greater than that of the compressive strength. The results of non-destructive evaluations revealed that the compressive strength could not be estimated correctly by the probe method using the manufacturer's conversion charts. Because of lower rebound readings, the rebound hammer could not be used to estimate the compressive strength at early ages.

17. KEY WORDS (six to twelve entries; alphabetical order; capitalize only the first letter of the first key word unless a proper name; separated by semicolons) Compressive strength; concrete; maturity; mechanical properties non-destructive evaluation; pull-out strength; splitting tensile strength.

18. AVAILABILITY

For Official Distribution. Do Not Release to NTIS

XI Order From Sup, of Doc., U.S. Government Pripting Office Washington, D.C. $20402, \mathrm{SD}$ Cat. No. C13, $46: 932$

Order From National Technical Information Service (NTIS) Springfield, Virginia 22151

\begin{tabular}{l|c|}
$\begin{array}{l}\text { 19. SECURITY CLASS } \\
\text { (THIS REPURT) }\end{array}$ & 56 \\
UNCLASSIFIED & 21. NO. OF PAGES \\
\hline $\begin{array}{l}\text { 20. SECURITY CLASS } \\
\text { (THIS PAGE) }\end{array}$ & $\begin{array}{c}\text { 22. Price } \\
\$ 1.35\end{array}$ \\
UNCLASSIFIED &
\end{tabular}




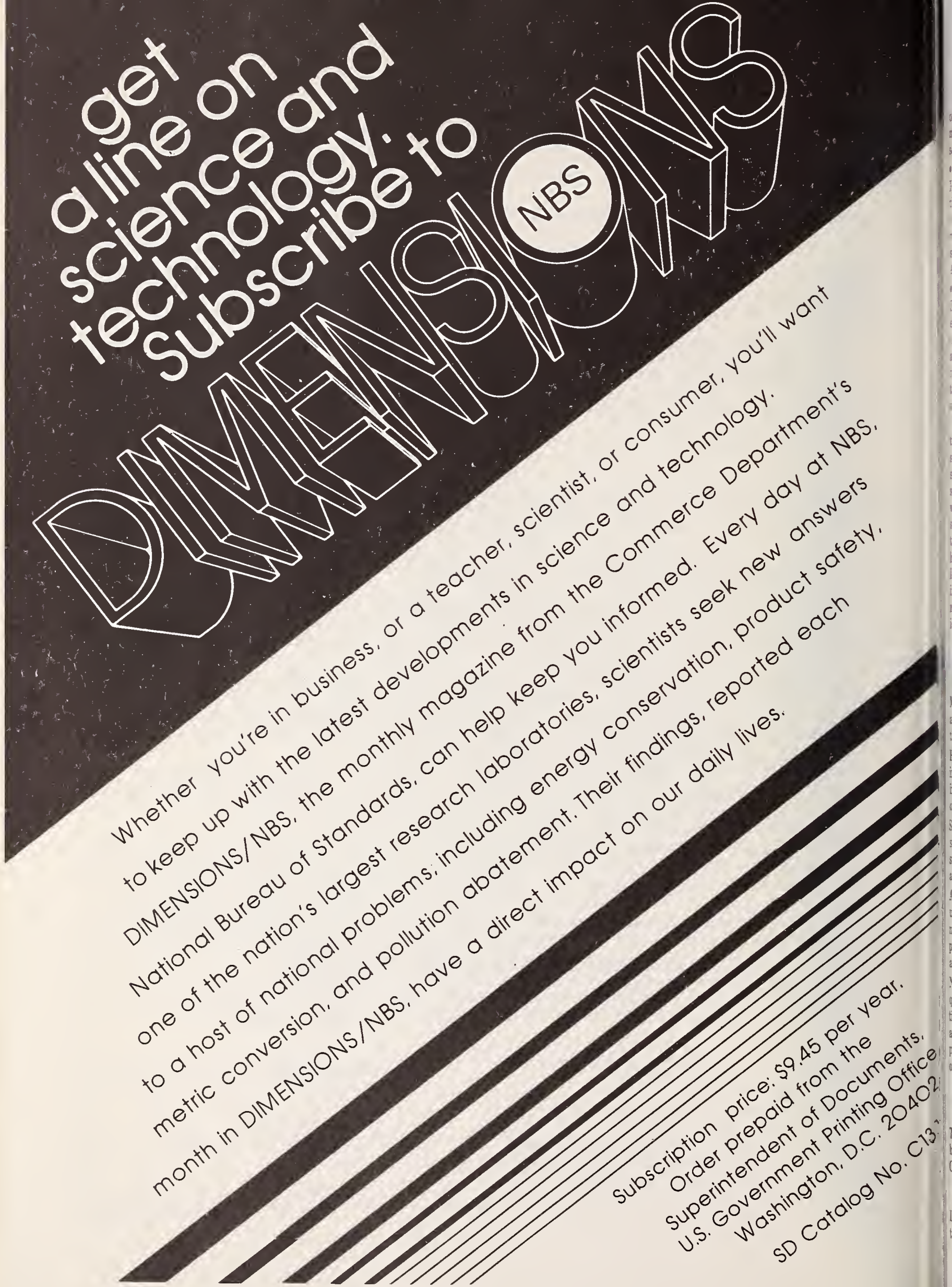




\section{PERIODICALS}

JOURNAL OF RESEARCH reports National Bureau of Standards research and development in physics, mathematics, and chemistry. It is published in two sections, available separately:

- Physics and Chemistry (Section A)

Papers of interest primarily to scientists working in these fields. This section covers a broad range of physical and chemical research, with major emphasis on standards of physical measurement, fundamental constants, and properties of matter. Issued six times a year. Annual subscription: Domestic, $\$ 17.00$; Foreign, $\$ 21.25$.

- Mathematical Sciences (Section B)

Studies and compilations designed mainly for the mathematician and theoretical physicist. Topics in mathematical statistics, theory of experiment design, numerical análysis, theoretical physics and chemistry, logical design and programming of computers and computer systems. Short numerical tables. Issued quarterly. Annual subscription: Domestic, \$9.00; Foreign, $\$ 11.25$.

DIMENSIONS/NBS (formerly Technical News Bulletin)-This monthly magazine is published to inform scientists, engineers, businessmen, industry, teachers, students, and consumers of the latest advances in science and technology, with primary emphasis on the work at NBS. The magazine highlights and reviews such issues as energy research, fire protection, building technology, metric conversion, pollution abatement, health and safety, and consumer product performance. In addition, it reports the results of Bureau programs in measurement standards and techniques, properties of matter and materials, engineering standards and services, instrumentation, and automatic data processing.

Annual subscription: Domestic, $\$ 9.45$; Foreign, $\$ 11.85$.

\section{NONPERIODICALS}

Monographs-Major contributions to the technical literature on various subjects related to the Bureau's scientific and technical activities.

Handbooks-Recommended codes of engineering and industrial practice (including safety codes) developed in cooperation with interested industries, professional organizations, and regulatory bodies.

Special Publications-Include proceedings of conferences sponsored by NBS, NBS annual reports, and other special publications appropriate to this grouping such as wall charts, pocket cards, and bibliographies.

Applied Mathematics Series-Mathematical tables, manuals, and studies of special interest to physicists, engineers, chemists, biologists, mathematicians, computer programmers, and others engaged in scientific and technical work.

National Standard Reference Data Series-Provides quantitative data on the physical and chemical properties of materials, compiled from the world's literature and critically evaluated. Developed under a world-wide program coordinated by NBS. Program under authority of National Standard Data Act (Public Law 90-396).
NOTE: At present the principal publication outlet for these data is the Journal of Physical and Chemical Reference Data (JPCRD) published quarterly for NBS by the American Chemical Society (ACS) and the American Institute of Physics (AIP). Subscriptions, reprints, and supplements available from ACS, 1155 Sixteenth St. N.W., Wash. D. C. 20056.

Building Science Series-Disseminates technical information developed at the Bureau on building materials, components, systems, and whole structures. The series presents research results, test methods, and performance criteria related to the structural and environmental functions and the durability and safety characteristics of building elements and systems.

Technical Notes-Studies or reports which are complete in themselves but restrictive in their treatment of a subject. Analogous to monographs but not so comprehensive in scope or definitive in treatment of the subject area. Often serve as a vehicle for final reports of work performed at NBS under the sponsorship of other government agencies.

Voluntary Product Standards-Developed under procedures published by the Department of Commerce in Part 10, Title 15, of the Code of Federal Regulations. The purpose of the standards is to establish nationally recognized requirements for products, and to provide all concerned interests with a basis for common understanding of the characteristics of the products. NBS administers this program as a supplement to the activities of the private sector standardizing organizations.

Consumer Information Series-Practical information, based on NBS research and experience, covering areas of interest to the consumer. Easily understandable language and illustrations provide useful background knowledge for shopping in today's technological marketplace.

Order above NBS publications from: Superintendent of Documents, Government Printing Office, Washington, D.C. 20402 .

Order following NBS publications-NBSIR's and FIPS from the National Technical Information Services, Springfield, Va. 22161.

Federal Information Processing Standards Publications (FIPS PUBS)_Publications in this series collectively constitute the Federal Information Processing Standards Register. Register serves as the official source of information in the Federal Government regarding standards issued by NBS pursuant to the Federal Property and Administrative Services Act of 1949 as amended, Public Law 89-306 (79 Stat. 1127), and as implemented by Executive Order 11717 (38 FR 12315, dated May 11, 1973) and Part 6 of Title 15 CFR (Code of Federal Regulations).

NBS Interagency Reports (NBSIR)-A special series of interim or final reports on work performed by NBS for outside sponsors (both government and non-government). In general, initial distribution is handled by the sponsor; public distribution is by the National Technical Information Services (Springfield, Va. 22161) in paper copy or microfiche form.

\section{BIBLIOGRAPHIC SUBSCRIPTION SERVICES}

The following current-awareness and literature-survey bibliographies are issued periodically by the Bureau:

Cryogenic Data Center Current Awareness Service. A literature survey issued biweekly. Annual subscription: Domestic, \$20.00; Foreign, \$25.00.

Liquified Natural Gas. A literature survey issued quarterly. Annual subscription: $\$ 20.00$.
Superconducting Devices and Materials. A literature survey issued quarterly. Annual subscription: $\$ 20.00$. Send subscription orders and remittances for the preceding bibliographic services to National Bureau of Standards, Cryogenic Data Center (275.02) Boulder, Colorado 80302. 
National Bureau of Standards

Washington, D.C. 20234

POSTAGE ANO FEES PAID

U.S. DEPARTMENT OF COMMERCE $C O M=295$

OFFICIAL BUSINESS

Penalty for Private Use, $\$ 300$

SPECIAL FOURTH-CLASS RATE BOOK

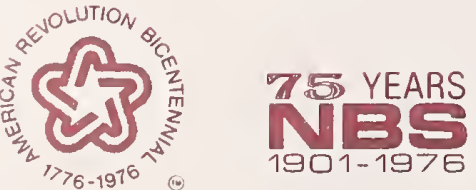

